medRxiv preprint doi: https://doi.org/10.1101/2021.06.07.21258350; this version posted June 8, 2021. The copyright holder for this preprint (which was not certified by peer review) is the author/funder, who has granted medRxiv a license to display the preprint in perpetuity.

\title{
1 Recognition and inhibition of SARS-CoV-2 by humoral innate immunity pattern
} recognition molecules

4 Matteo Stravalaci ${ }^{1,2^{*}}$, Isabel Pagani ${ }^{3 *}$, Elvezia Maria Paraboschi ${ }^{1,2}$, Mattia Pedotti $^{4}$, Andrea

5 Doni $^{1}$, Francesco Scavello ${ }^{1}$, Sarah N. Mapelli ${ }^{1}$, Marina Sironi ${ }^{1}$, Luca Varani ${ }^{4}$, Milos

6 Matkovic $^{4}$, Andrea Cavalli ${ }^{4,5}$, Daniela Cesana ${ }^{6}$, Pierangela Gallina ${ }^{7}$, Nicoletta Pedemonte ${ }^{7}$,

$7 \quad$ Valeria Capurro ${ }^{7}$, Nicola Clementi $^{8}$, Nicasio Mancini ${ }^{8}$, Pietro Invernizzi ${ }^{9}, 10$, Rino

8 Rappuoli ${ }^{11,12}$, Stefano Duga ${ }^{1,2}$, Barbara Bottazzi ${ }^{1}$, Mariagrazia Uguccioni ${ }^{4,2}$, Rosanna

9 Asselta ${ }^{1,2}$, Elisa Vicenzi ${ }^{3, \S}$, Alberto Mantovani, $^{1,2,13, \S}$, Cecilia Garlanda ${ }^{1,2, \S}$

${ }^{1}$ IRCCS Humanitas Research Hospital, via Manzoni 56, 20089 Rozzano (Milan), Italy;

${ }^{2}$ Department of Biomedical Sciences, Humanitas University, Via Rita Levi Montalcini 4, 20090 Pieve Emanuele (Milan), Italy;

${ }^{3}$ Viral Pathogenesis and Biosafety Unit, IRCCS San Raffaele Scientific Institute, Milan, Italy

${ }^{4}$ Institute for Research in Biomedicine, Università della Svizzera italiana (USI), Bellinzona,

17 Switzerland.

${ }^{5}$ Swiss Institute of Bioinformatics, Lausanne, Switzerland

${ }^{6}$ San Raffaele Telethon Institute for Gene Therapy (SR-Tiget); IRCCS, San Raffaele

Scientific Institute, Milan, Italy.

${ }^{7}$ UOC Genetica Medica, IRCCS Istituto Giannina Gaslini, Via Gaslini 5, 16147 Genova

Raffaele University, Milan Italy.

$24{ }^{9}$ Division of Gastroenterology, Center for Autoimmune Liver Diseases, Department of

25 Medicine and Surgery, University of Milano-Bicocca, Monza, Italy

NOTE: This preprint reports new research that has not been certified by peer review and should not be used to guide clinical practice. 
medRxiv preprint doi: https://doi.org/10.1101/2021.06.07.21258350; this version posted June 8, 2021. The copyright holder for this preprint (which was not certified by peer review) is the author/funder, who has granted medRxiv a license to display the preprint in perpetuity. All rights reserved. No reuse allowed without permission.

$26{ }^{10}$ European Reference Network on Hepatological Diseases (ERN RARE-LIVER), San Gerardo

27 Hospital, Monza, Italy

$28{ }^{11}$ Monoclonal Antibody Discovery Lab, Fondazione Toscana Life Sciences, Siena, Italy.

$29{ }^{12}$ Faculty of Medicine, Imperial College London, London, UK.

$30{ }^{13}$ The William Harvey Research Institute, Queen Mary University of London, Charterhouse

31 Square, London EC1M 6BQ.

$32 *$ equally contributed

33 §Corresponding authors: cecilia.garlanda@humanitasresearch.it,

34 alberto.mantovani@humanitasresearch.it, vicenzi.elisa@hsr.it 
medRxiv preprint doi: https://doi.org/10.1101/2021.06.07.21258350; this version posted June 8,2021 . The copyright holder for this preprint (which was not certified by peer review) is the author/funder, who has granted medRxiv a license to display the preprint in perpetuity. All rights reserved. No reuse allowed without permission.

\section{Summary}

37 The humoral arm of innate immunity includes diverse molecules with antibody-like functions,

38 some of which serve as disease severity biomarkers in COVID-19. The present study was

39 designed to conduct a systematic investigation of the interaction of humoral fluid phase pattern

40 recognition molecules (PRM) with SARS-CoV-2. Out of 10 PRM tested, the long pentraxin

41 PTX3 and Mannose Binding Lectin (MBL) bound the viral Nucleoprotein and Spike,

42 respectively. MBL bound trimeric Spike, including that of variants of concern, in a glycan-

43 dependent way and inhibited SARS-CoV-2 in three in vitro models. Moreover, upon binding

44 to Spike, MBL activated the lectin pathway of complement activation. Genetic polymorphisms

45 at the MBL locus were associated with disease severity. These results suggest that selected

46 humoral fluid phase PRM can play an important role in resistance to, and pathogenesis of,

47 COVID-19, a finding with translational implications. 
medRxiv preprint doi: https://doi.org/10.1101/2021.06.07.21258350; this version posted June 8, 2021. The copyright holder for this preprint (which was not certified by peer review) is the author/funder, who has granted medRxiv a license to display the preprint in perpetuity.

\section{Introduction}

SARS-CoV-2 is a highly pathogenic coronavirus and the causative agent of the current

et al., 2020). Innate immunity is credited to play a fundamental role in this condition and may eradicate the infection in its early phases, before adaptive immune responses take place. In severe forms of the disease, uncontrolled activation of innate and adaptive immunity results in hyperinflammatory responses, which affect the lung and blood vessels, contributing to ARDS, shock and multiorgan failure (Wang et al., 2020).

Innate immunity includes a cellular and a humoral arm (Bottazzi et al., 2010). The humoral arm consists in soluble PRMs belonging to different families, which include collectins [e.g. mannose binding lectin (MBL)], ficolins, pentraxins [C-reactive protein (CRP), Serum amyloid P component (SAP), pentraxin 3 (PTX3)], and C1q (Bottazzi et al., 2010; Garlanda et al., 2018; Holmskov et al., 2003). Humoral PRMs represent functional ancestors of antibodies (ante-antibodies), as they recognize microbial components and eliminate pathogens with common mechanisms that include agglutination, neutralization, activation of the complement cascade and opsonization facilitating phagocytosis (Bottazzi et al., 2010). Investigations of the role of humoral innate immunity in viral sensing have shown that collectins bind to envelope glycoproteins on enveloped viruses, including influenza virus, human immunodeficiency virus, hepatitis $\mathrm{C}$ virus (HCV) and herpes simplex virus, as well as to the nonenveloped rotavirus (Holmskov et al., 2003). Interaction may result in opsonization, agglutination, inhibition of viral fusion and entry, or complement activation, generally leading to inhibition of infection (Holmskov et al., 2003). Among pentraxins, the long pentraxin PTX3 has been show to interact with H3N2-subtype influenza virus type A by interacting with viral envelope hemagglutinin and neuraminidase glycoproteins through a sialic acid residue on its glycosidic moiety (Reading et al., 2008), with cytomegalovirus (CMV) (Bozza et al., 2006), and with the 
medRxiv preprint doi: https://doi.org/10.1101/2021.06.07.21258350; this version posted June 8, 2021. The copyright holder for this preprint (which was not certified by peer review) is the author/funder, who has granted medRxiv a license to display the preprint in perpetuity. All rights reserved. No reuse allowed without permission.

coronavirus murine hepatitis virus strain 1 (MHV-1) (Han et al., 2012), preventing viral infection.

Several lines of evidence, including genetic associations, indicate that cellular innate immunity, and related cytokines and chemokines, play a key role in SARS-CoV-2 recognition, antiviral resistance and, at later stages, severe disease (Merad and Martin, 2020; PairoCastineira et al., 2021; Severe Covid et al., 2020; Zhang et al., 2020). In contrast, little information is available concerning the role of the humoral arm of innate immunity in COVID19 resistance and pathogenesis, in spite of the clinical prognostic significance of CRP and PTX3 (Brunetta et al., 2021; Fajgenbaum and June, 2020).

The present study was designed to conduct a systematic investigation of the interaction of the humoral PRM with SARS-CoV-2. We found that PTX3 and MBL bound the SARSCoV-2 Nucleoprotein and Spike, respectively. MBL recognized variants of concern (VoC), had antiviral activity and activated the Complement lectin pathway. Genetic polymorphisms at the MBL locus were associated with disease severity. Thus, selected fluid phase PRM (anteantibodies) play an important role in resistance to, and pathogenesis of, COVID-19, a finding with translational implications.

\section{Results}

\section{Interaction of humoral pattern recognition molecules with SARS-CoV-2 proteins}

To study the role of humoral PRMs in recognizing SARS-CoV-2, we first investigated the interaction between humoral innate immunity molecules and SARS-CoV-2 proteins using a solid phase binding assay. We first analysed pentraxins and, as shown in Figure 1A and 1B, we did not observe specific binding of CRP and SAP to any of the SARS-CoV-2 proteins tested (S1, S2, S protein active trimer, Nucleocapsid, Envelope protein). In contrast, PTX3 bound specifically and in a dose-dependent manner to the Nucleocapsid protein, one of the most 
medRxiv preprint doi: https://doi.org/10.1101/2021.06.07.21258350; this version posted June 8, 2021. The copyright holder for this preprint (which was not certified by peer review) is the author/funder, who has granted medRxiv a license to display the preprint in perpetuity. All rights reserved. No reuse allowed without permission.

abundant proteins of SARS-CoV-2 (Zeng et al., 2020) (Figure 1C). We validated this result by confirming the binding of PTX3 with SARS-CoV-2 Nucleocapsid protein produced obtained from different sources. PTX3 is a multimeric glycoprotein arranged in an octameric structure. Each protomer is constituted of a flexible N-terminal region and a C-terminal domain with homology to the short pentraxin family (Bottazzi et al., 2010). To define which portion of the molecule was involved in the interaction, we compared the binding of full length PTX3 and its $\mathrm{N}$-terminal or C-terminal domains to SARS-CoV-2 Nucleocapsid protein. Results indicate that PTX3 interacts with SARS-CoV-2 Nucleocapsid protein mainly through its N-terminal domain, although with lower affinity compared to full length PTX3 (Figure 1D).

We next investigated the interaction between PRMs of the classical and the lectin pathway of complement (C1q and the collectin $\mathrm{MBL}$, respectively) and the viral proteins. As shown in Figure 2A, C1q did not interact with any protein tested. In contrast, human MBL bound to SARS-CoV-2 Spike protein (Wuhan strain (Wu et al., 2020), active trimer), but not to the individual SARS-CoV-2 Spike subunits S1 [containing the receptor-binding domain (RBD)] and S2 (containing the membrane fusion domain) (Figure 2B). We validated these data by analyzing the binding of MBL to different recombinant SARS-CoV-2 Spike proteins obtained from different sources or produced in house either in HEK293 cells, or CHO cells, or in insect cells (Figure 2C and Extended Data Figure 1). All these preparations were bound by MBL, although with some differences. Notably, when we tested a non-covalent trimer of the SARS-CoV-2 Spike protein, we did not observe binding. These results indicate that a nativeclose structure of the SARS-CoV-2 Spike protein (presumably in the trimeric conformation) is indispensable for MBL recognition.

MBL is a member of the collectin family, a class of PRMs composed of a $\mathrm{Ca}^{2+}-$ type lectin domain (also called Carbohydrate Recognition Domain, CRD) and a collagen-like domain (Holmskov et al., 2003). Thus, we analyzed the interaction of SARS-CoV-2 Spike 
medRxiv preprint doi: https://doi.org/10.1101/2021.06.07.21258350; this version posted June 8, 2021. The copyright holder for this preprint (which was not certified by peer review) is the author/funder, who has granted medRxiv a license to display the preprint in perpetuity. All rights reserved. No reuse allowed without permission.

protein with other collectins involved in innate immunity, such as Collectin-12 (CLP-1) and the pulmonary surfactant proteins SP-A and SP-D. We also extended the analysis to recombinant Ficolin-1, -2, or -3, a family of proteins known to activate the complement lectin pathway, and structurally-related to MBL. As shown in Figure 2D and 2E, in contrast with MBL, CLP-1, SP-A, SP-D, and ficolins did not bind to SARS-CoV-2 Spike protein, indicating that recognition of Spike is unique to MBL.

We further characterized the interaction of SARS-CoV-2 Spike protein with MBL by Surface Plasmon Resonance (SPR). Different concentrations of recombinant, SARS-CoV-2 Spike protein or RBD domain were flowed onto MBL immobilized on the biosensor surface. As shown in Figure 2F and Extended Data Figure 2, trimeric SARS-CoV-2 Spike protein formed a stable calcium-dependent complex with nanomolar affinity $\left(K_{D}=34 \mathrm{nM}\right)$ whereas MBL did not bind the isolated RBD, confirming the results obtained using the $\mathrm{S} 1$ subunit.

To mimic the interaction between MBL and SARS-CoV-2 Spike protein in its physiological conformation in the viral envelope, we investigated the binding of viral particles of SARS-CoV-2 Spike protein pseudotyped on a lentivirus vector to MBL-coated plates. The interaction was determined by lysing the bound pseudovirus and measuring the lentiviral vector p24 core protein by ELISA. While control lentiviral particles pseudotyped with the VSV-g glyprotein (VSV-pseudovirus) did not result in any binding, those exposing the SARS-CoV-2 Spike protein showed a specific interaction with MBL (Figure 3A). These data strongly suggest that MBL can also interact with the SARS-CoV-2 Spike protein exposed on the virus surface.

\section{MBL interacts with glycosidic sites of the SARS-CoV-2 spike protein}

The SARS-CoV-2 Spike protein is highly glycosylated, as recently described (Watanabe et al., 2020). Out of the $22 \mathrm{~N}$-glycosylation sites, 8 contain oligomannose-types glycans, which could be interaction sites for the MBL carbohydrate recognition domain (CRD). 
medRxiv preprint doi: https://doi.org/10.1101/2021.06.07.21258350; this version posted June 8, 2021. The copyright holder for this preprint (which was not certified by peer review) is the author/funder, who has granted medRxiv a license to display the preprint in perpetuity. All rights reserved. No reuse allowed without permission.

149 To address this possibility, we performed a solution-based competition assay with D-mannose and N-acetyl-glucosamine, two specific ligands of the lectin. As shown in Figure 3B, D-

151 mannose and N-acetyl-glucosamine inhibited MBL binding to the Spike protein, thus

152 confirming the $\mathrm{Ca}^{2+}$-dependent interaction between the MBL lectin domain and the glycosidic

153 sites exposed by the Spike protein. D-Glucose, a non-specific ligand of MBL, inhibited the interaction only at higher concentration (Figure 3B). Based on the alignment of MBL crystal structure with mannose molecules (Fig. 3C), we identified 14 putative binding sites on the Spike protein (Fig. 3D). Next, we considered sites having a high (>80\%) oligomannosylation occupancy (Watanabe et al., 2020). This analysis provided two possible MBL binding sites, namely N603, N801 and N1074 all on the same Spike chain, or N603, N1074 and N709 with N709 on a neighboring chain (Figure 3E). Interestingly, in both cases, the hypothesized MBL binding sites spans across the $\mathrm{S} 1$ and $\mathrm{S} 2$ region (Figure 3F) of the Spike protein providing hints to a possible inhibition mechanism. These data indicate that the glycosylation state of the SARS-CoV-2 Spike protein is important for its interaction with MBL.

\section{Interaction of MBL with Spike from VoC}

We then tested whether MBL recognized Spike proteins from VoC. First, we analyzed mutations. Figure $3 \mathrm{G}$ shows a schematic representation of the 22 positions of N-linked glycosylation sequons and of 35 known mutations, indicating that none of these mutations

169 involve the glycosylation sites, and suggesting that MBL could interact with the variants with

170 the same affinity. In agreement with our binding assays, no MBL target sites are expected in

171 the RBD. We assessed by solid phase assay the interaction of MBL with the SARS-CoV-2

172 D614G Spike trimeric protein, the B.1.1.7 variant (emerged in UK), the B.1.1.28 or P.1 variant 
medRxiv preprint doi: https://doi.org/10.1101/2021.06.07.21258350; this version posted June 8, 2021. The copyright holder for this preprint (which was not certified by peer review) is the author/funder, who has granted medRxiv a license to display the preprint in perpetuity. All rights reserved. No reuse allowed without permission.

173 (emerged in Brazil), and B.1.351 (emerged in South Africa) (Figure 3H). In agreement with

174 the in silico analysis, MBL bound the VoC Spike proteins tested with similar affinity.

176 Complement lectin pathway activation

177 We asked whether the interaction of MBL with Spike could activate the complement 178 lectin pathway. We incubated SARS-CoV-2 Spike protein-coated plates with human serum, or

179 C1q- or C4- or C3-depleted serum, and we assessed the deposition of C5b-9. As shown in

180 Figure 3I (left panel), incubation with either normal human serum or C1q-depleted serum

181 resulted in complement deposition mediated by SARS-CoV-2 Spike protein. Conversely,

182 incubation with a serum depleted of C4 strongly reduced C5b-9 deposition, with levels 183 comparable to those observed with heat-inactivated serum or C3-depleted serum.

184 Reconstitution of C4-depleted serum with purified C4 restored C5b-9 deposition levels similar

185 to those observed with normal human serum. To further address the role of MBL in SARS-

186 CoV-2 Spike protein-mediated complement activation, we assessed C5b-9 deposition by 187 incubating normal human serum or MBL-immunodepleted serum over captured SARS-CoV-2 188 Spike protein, either as active, or non-covalent trimer (Figure 3I, right panel). In agreement 189 with binding data, no complement deposition was observed with the non-covalent trimeric 190 Spike protein. Notably, immunodepletion of MBL from human serum resulted in a significant 191 reduction in C5b-9 deposition, which could be fully reverted by addition of rhMBL (Figure 3I, 192 right panel). These data clearly indicate that SARS-CoV-2 Spike, by interacting with MBL, 193 activates the complement lectin pathway.

\section{SARS-CoV-2 inhibition by MBL}

To validate the relevance of the interaction between MBL and SARS-CoV-2 Spike

197 protein, we investigate whether MBL inhibited SARS-CoV-2 entry in susceptible cells. We 
medRxiv preprint doi: https://doi.org/10.1101/2021.06.07.21258350; this version posted June 8, 2021. The copyright holder for this preprint (which was not certified by peer review) is the author/funder, who has granted medRxiv a license to display the preprint in perpetuity. All rights reserved. No reuse allowed without permission.

198 first tested the effect of MBL and other soluble PRMs (10-fold serial dilution, from 0.01 to 10

$199 \mu \mathrm{g} / \mathrm{ml}$ ) on the entry of the viral particles of SARS-CoV-2 Spike protein pseudotyped on a

200 lentivirus vector in 293T cells overexpressing Angiotensin-Converting Enzyme 2 (ACE2).

201 Among the soluble PRMs tested, MBL was found to be the only molecule with anti-SARS-

202 CoV-2 activity. Spike-mediated viral entry was inhibited by $90 \%$ at the highest concentration 203 of $10 \mu \mathrm{g} / \mathrm{ml}(34 \mathrm{nM})$ with an EC50 value of approximately $0.5 \mu \mathrm{g} / \mathrm{ml}(1.7 \mathrm{nM})$ (Figure 4A).

204 As control, entry of lentiviral particles pseudotyped with the VSV-g glycoprotein was not inhibited by MBL (Figure 4A).

We next tested the antiviral activity of MBL on the SARS-CoV-2 infection of lung epithelial models relevant to human infections. Among a number of lung-derived epithelial cell lines, Calu-3 (human lung adenocarcinoma) cells have been shown to be permissive to SARSCoV-2 infection (Chu et al., 2020). SARS-CoV-2 (D614G variant, MOI=0.1 and 1) was preincubated in complete medium containing different concentrations of MBL (0.01-10 $\mu \mathrm{g} / \mathrm{mL} ; 0.034-34 \mathrm{nM}$ ) before incubation with Calu-3 cells. After 48 and $72 \mathrm{~h}$, the infectivity of

212 SARS-CoV-2 present in cell culture supernatants was determined by a plaque-forming assay

213 in monkey-derived Vero cells. Vero cells are a handy cell line used worldwide as it is devoid 214 of the interferon (IFN) response (Desmyter et al., 1968) and, for this reason, highly supportive 215 of virus replication.

216 As shown in Extended Data Figure 3A, MBL showed a concentration-dependent inhibition 217 of SARS-CoV-2 infection of Calu-3 cells at MOI 0.1 (upper panel) and 1 (lower panel), that 218 was statistically significant at 1 and $10 \mu \mathrm{g} / \mathrm{ml}(3.4$ and $34 \mathrm{nM}) 72 \mathrm{~h}$ after infection. When both 219 virus and cells were pre-incubated with the same concentrations of MBL $(0.01-10 \mu \mathrm{g} / \mathrm{mL}$; 0.034-34 $\mathrm{nM})$, the antiviral activity increased significantly from $0.1 \mu \mathrm{g} / \mathrm{ml}(0.34 \mathrm{nM})$ to the top concentration of $10 \mu \mathrm{g} / \mathrm{ml}(34 \mathrm{nM}), 72 \mathrm{~h}$ post-infection (PI) (Figure 4B and Extended Data

222 Figure 3B). The calculated EC50 was $0.08 \mu \mathrm{g} / \mathrm{mL}(0.27 \mathrm{nM})$ at $72 \mathrm{~h}$. Notably, MBL showed 
medRxiv preprint doi: https://doi.org/10.1101/2021.06.07.21258350; this version posted June 8, 2021. The copyright holder for this preprint (which was not certified by peer review) is the author/funder, who has granted medRxiv a license to display the preprint in perpetuity. All rights reserved. No reuse allowed without permission.

a concentration-dependent inhibition of infection of Calu-3 cells also by SARS-CoV-2 variant 20I/501Y.V1 (B.1.1.7) at MOI 1 (Figure 4C) and MOI 0.1 (Extended Data Figure 3C), as well as by $20 \mathrm{H} / 501 \mathrm{Y} . \mathrm{V} 2$ (B.1.351) at MOI 1 (Figure 4D).

Furthermore, a model of 3D-human bronchial epithelial cells (HBEC) was used to test whether MBL inhibited SARS-CoV-2 replication. SARS-CoV-2 production at the epithelial apical surface increased sharply at $48 \mathrm{~h}$ PI (not shown), reaching $48 \times 10^{6} \pm 6 \times 10^{6}$ (mean \pm SEM) PFU/ml 72 h PI. Treatment of HBEC with MBL decreased viral production to $4 \times 10^{6} \pm 0.8 \times 10^{6} \mathrm{PFU} / \mathrm{ml} 72 \mathrm{~h}$ PI at the highest concentration of $50 \mu \mathrm{g} / \mathrm{ml}(170 \mathrm{nM}$ ) (Figure 5A). In contrast PTX3 treatment was ineffective at inhibiting virus production (Extended Data Figure 3D). We then assessed whether in these experimental conditions, MBL affected inflammatory responses in HBEC upon SARS-CoV-2 infection. As shown in Extended Data Figure 3E, MBL treatment inhibited the production of IL-8 and CXCL5, chemokines involved in myeloid cell recruitment and activation.

We finally evaluated occurrence of MBL-Spike protein interaction in SARS-CoV-2 infected HBEC by confocal microscopy. As shown in Figure 5B and C, MBL colocalized with SARS-CoV-2 Spike protein in infected cells. In 3D rendered images of the HBEC cell cultures (Figure 5D and Movie S1), colocalization was preferentially associated to the apical side of cytokeratin 14 positive cells. Evidence of the interaction between MBL and SARS-CoV-2 Spike protein in infected HBEC at molecular scale $(<100 \mathrm{~nm} X Y$ spatial resolution) were also obtained in STED-based super-resolution microscopy (Figure 5E).

\section{MBL2 haplotypes are associated with severe COVID-19}

MBL2 genetic variants have been shown to correlate with increased susceptibility to selected infections, including SARS (Ip et al., 2005). To explore the significance of our in vitro results in the frame of COVID-19 pandemic, we investigated the possible association of $M B L 2$ 
medRxiv preprint doi: https://doi.org/10.1101/2021.06.07.21258350; this version posted June 8, 2021. The copyright holder for this preprint (which was not certified by peer review) is the author/funder, who has granted medRxiv a license to display the preprint in perpetuity. All rights reserved. No reuse allowed without permission.

polymorphisms with severe COVID-19 with respiratory failure in an Italian cohort of 332 cases and 1,668 controls (general population). We initially focused on six SNPs known to be associated with MBL2 protein levels (Table 1) (Lipscombe et al., 1992; Madsen et al., 1994; Madsen et al., 1995; Sumiya et al., 1991). Surprisingly, we observed a significant difference only in the frequency of the rs5030737-A allele between patients and controls $(7.7 \%$ and $6.0 \%$, respectively; $\mathrm{OR}=1.43,95 \% \mathrm{CI}=1.00-2.05, \mathrm{P}=0.049$; Table $1 \mathrm{~A}$ ), which however did not survive the correction for multiple testing. When we compared the frequencies of haplotypes determined by all six SNPs, we found the CCGGCC haplotype frequency significantly decreased in patients with severe COVID-19 (26.7\% in cases, $30.4 \%$ in controls). This haplotype shows a protective effect (odds ratio $(\mathrm{OR})=0.78,95 \% \mathrm{CI}=0.65-0.95, \mathrm{P}=0.025$; Table 1B), consistently with the lack of the rs5030737-A allele, which is only present in the CCAGCC haplotype $(\mathrm{OR}=1.38,95 \% \mathrm{CI}=1.00-1.90 ; \mathrm{P}=0.078$; Table 1B)

Though borderline, these first association results encouraged us to investigate the 1Mb-long genomic region encompassing the MBL2 gene systematically. To this aim, we performed single-SNP as well as haplotype-based association analyses using genotyped/imputed data on 3,425 polymorphisms. Single-SNP association analysis revealed three suggestive signals $\quad\left(\mathrm{rs} 150342746, \quad \mathrm{OR}=3.47, \quad 95 \% \mathrm{CI}=1.81-6.68, \quad \mathrm{P}=1.86^{*} 10^{-4}\right.$; rs 10824845, $\mathrm{OR}=1.76, \quad 95 \% \mathrm{CI}=1.30-2.39, \quad \mathrm{P}=2.91 * 10^{-4} ; \quad$ and $\quad \mathrm{rs} 11816263, \quad \mathrm{OR}=1.42$, $95 \% \mathrm{CI}=1.17-1.73, \mathrm{P}=3.47 * 10^{-4}$; Table 1C; Figure 6), whereas haplotype-based analysis disclosed 7 haplotypes of different lengths, from 2 to 24 SNPs, strongly associated with severe COVID-19 (all surviving the correction for multiple tests; Figure 6; Table 1D). Among them, the one composed of polymorphisms rs10824844-rs10824845 incorporates one of the two topmarkers evidenced by the single-SNP association analysis and is present in $12.2 \%$ of cases and $6.9 \%$ of controls (TA haplotype, $\mathrm{OR}=1.88,95 \% \mathrm{CI}=1.44-2.45, \mathrm{P}=1.04 * 10^{-5}$; Table 1D). Hence, we performed a meta-analysis based on the rs 10824845 polymorphism by including the GHS 
medRxiv preprint doi: https://doi.org/10.1101/2021.06.07.21258350; this version posted June 8, 2021. The copyright holder for this preprint (which was not certified by peer review) is the author/funder, who has granted medRxiv a license to display the preprint in perpetuity. All rights reserved. No reuse allowed without permission.

study of COVID-19 patients: this resulted in a pooled $\mathrm{OR}=1.32,95 \% \mathrm{CI}=1.15-1.52, \mathrm{P}=9.12^{*} 10^{-}$ 5 (Table 1E). Notably, the rs10824845 polymorphism points to a regulatory region characterized by the presence of an enhancer (GH10J052964), described as a distant modulator of the MBL2 gene, active in HepG2 cells (hepatocytes), as well as M0 (from venous blood) and M1 (from cord and venous blood) macrophages (data from the GeneHancer database, available through http://www.genecards.org/).

\section{Discussion}

Among the 10 fluid phase PRM tested in this study, only PTX3 and MBL bound SARSCoV-2 virus components. PTX3 recognized the viral Nucleoprotein and had no antiviral activity. PTX3 was expressed at high levels by myeloid cells in blood and lungs and its plasma levels have strong and independent prognostic significance for death in COVID-19 patients (Brunetta et al., 2021; Schirinzi et al., 2021). It remains to be elucidated whether PTX3 plays a role in Nucleocapsid-mediated complement activation and cytokine production (Gao et al., 2020; Karwaciak et al., 2021; McBride et al., 2014).

MBL recognized the SARS-CoV-2 Spike protein, including that of three $\mathrm{VoC}$, and had antiviral activity in vitro. MBL had previously been shown to bind SARS-CoV Spike (Zhou et al., 2010). The interaction of MBL with Spike required a trimeric conformation of the viral protein, did not involve direct recognition of the RBD and was glycan-dependent, as expected. Site-specific glycosylation analysis of the SARS-CoV-2 Spike protein revealed the presence of various oligomannose-type glycans across the protein (Watanabe et al., 2020).

Molecular modelling reported here suggests that the MBL trimer interact with glycans attached to the residues N603, N801 and N1074 on the same chain or N603, N709 and N1074 with N709 on a different chain. In both cases the hypothesized MBL binding site spans across the S1 and S2 region of SARS-CoV-2 Spike, suggesting a possible neutralization mechanism. 
medRxiv preprint doi: https://doi.org/10.1101/2021.06.07.21258350; this version posted June 8, 2021. The copyright holder for this preprint (which was not certified by peer review) is the author/funder, who has granted medRxiv a license to display the preprint in perpetuity. All rights reserved. No reuse allowed without permission.

The binding of MBL could prevent the detachment of the S1 region and the release of the fusion peptide at position 815 , thus inhibiting virus entry into host cells. However, the mechanisms responsible for the antiviral activity of MBL remain to be fully defined. It is noteworthy that C-type lectins have been reported to act as entry receptors (or coreceptors) (Chiodo et al., 2020; Lempp et al., 2021; Lu et al., 2021) and MBL is likely to compete at this level.

$$
\text { reported until now do not affect glycosylation sites containing oligomannose-types glycans }
$$
potentially recognized by MBL. In addition, binding and infection experiments show that the anti-viral activity of MBL is not affected by these mutations. This indicate that the glycosylation sites are generally spared by selective pressure, suggesting they are essential for SARS-CoV-2 infectivity. It has been recently shown that mechanisms of in vitro escape of SARS-CoV-2 from a highly neutralizing COVID-19 convalescent plasma include the insertion of a new glycan sequon in the N-terminal domain of the Spike protein, which leads to complete resistance to neutralization (Andreano et al., 2020). This result further emphasizes the relevance of Spike glycosidic moieties targeted by MBL in SARS-CoV-2 infectivity.

MBL was found to interact with Spike and have antiviral activity with an EC50 of approximately $0.08 \mu \mathrm{g} / \mathrm{ml}(0.27 \mathrm{nM})$ and an affinity of $34 \mathrm{nM}$. These concentrations are well in the range of those found in the blood of normal individuals (up to $10 \mu \mathrm{g} / \mathrm{ml}$ ) which increase 2-3-fold during the acute phase response. MBL plasma levels in healthy individuals are extremely variable, in part depending on genetic variation in the $M B L 2$ gene. Defective MBL production has been associated with increased risk of infections, in particular in primary or secondary immunodeficient children (Koch et al., 2001). In SARS, conflicting results have been reported concerning the relevance of MBL2 genetic variants in this condition (Ip et al., 
medRxiv preprint doi: https://doi.org/10.1101/2021.06.07.21258350; this version posted June 8, 2021. The copyright holder for this preprint (which was not certified by peer review) is the author/funder, who has granted medRxiv a license to display the preprint in perpetuity. All rights reserved. No reuse allowed without permission.

2005; Yuan et al., 2005; Zhang et al., 2005). In COVID-19, one MBL2 SNP has been associated with development and severity of the infection (Medetalibeyoglu et al., 2021). We investigated the possible role of MBL2 genetic variants in determining susceptibility to severe COVID-19 with respiratory failure, by exploiting the statistical power provided by haplotype analysis. Surprisingly and in contrast with a previous study (Medetalibeyoglu et al., 2021), we found only a borderline correlation between one haplotype of the 6 SNPs associated with MBL levels and frequency of severe COVID-19 cases. However, we found a total of 7 significantly associated haplotypes, distributed along the $M B L 2$ genomic region, often mapping in correspondence of regulatory elements (such as enhancers, promoter region, histone marks; Figure 6). Our association data are reinforced by: i) the meta-analysis results, obtained by integrating the summary statistics from a European cohort of $>113,000$ individuals; ii) the fact that one of our second best associations (i.e., rs10824845) maps in proximity of a cluster of suggestive signals $\left(\mathrm{P}<5^{*} 10^{-4}\right)$ identified by the COVID-19 Host Genetic Initiative (https://www.covid19hg.org/; results on release 4 include data from up to 33 different worldwide studies; Figure 6); iii) the Regeneron - Genetic Center database, which contains association results also for rare variants $(\mathrm{MAF}<1 \%)$, reports a significant association $(\mathrm{P}<0.05)$ for the rs35668665 polymorphism both with susceptibility to COVID-19 (OR=4.11, GHS cohort) and with severity of symptoms ( $\mathrm{OR}=7.91$, UK BioBank cohort). Interestingly, this variant maps in correspondence of the last nucleotide of $M B L 2$ exon 1, thus possibly interfering with the splicing process; and iv) the rs5030737 (p.Arg52Cys) polymorphism in MBL2 has been described in the UKBiobank ICD PheWeb database (https://pheweb.org/UKB-SAIGE/) as a top signal in determining both "dependence on respirator [Ventilator] or supplemental oxygen" (ICD code Z99.1; $\mathrm{P}=2.7 * 10^{-4}$ ) and "Respiratory failure, insufficiency, arrest" (ICD code J96; $\mathrm{P}=2.7 * 10^{-3}$ ). These observations suggest that genetic variations in $M B L 2$, possibly involved in the modulation of the expression of the gene in hepatocytes, and, interestingly, in 
medRxiv preprint doi: https://doi.org/10.1101/2021.06.07.21258350; this version posted June 8, 2021. The copyright holder for this preprint (which was not certified by peer review) is the author/funder, who has granted medRxiv a license to display the preprint in perpetuity. All rights reserved. No reuse allowed without permission.

macrophages, could play a role in determining susceptibility to severe COVID-19 with respiratory failure. Therefore genetic analysis is consistent with the view that MBL recognition of SARS-CoV-2 plays an important role in COVID-19 pathogenesis.

Upon interaction with Spike, MBL was found to activate the lectin pathway of complement, as expected. Complement has been credited an important role in the hyperinflammation underlying severe disease and is considered a relevant therapeutic target (Carvelli et al., 2020; Risitano et al., 2020). Therefore, as for innate immunity in general including the IFN pathway (King and Sprent, 2021), MBL-mediated recognition of SARSCoV-2 may act as a double-edged sword. In early phases of the disease MBL, possibly produced locally by macrophages, may serve as a mechanism of antiviral resistance by blocking viral entry, whereas in advanced disease stages it may contribute to complement activation and uncontrolled inflammation.

MBL has been safely administered to patients with cystic fibrosis and chronic lung infections in which MBL deficiency contributes to pathogenesis (Garred et al., 2002; Jensenius et al., 2003). Therefore, the results presented here have translational implications both in terms of comprehensive genetic risk assessment and development of local or systemic therapeutic approaches.

\section{Acknowledgements}

This work was supported by a philanthropic donation by Dolce \& Gabbana fashion house (to A.M., C.G., E.V.), by the Italian Ministry of Health for COVID-19 (to A.M. and C.G.), the Italian Ministry of University and Research (to P.I.), by the Department of Excellence project PREMIA (PREcision MedIcine Approach: bringing biomarker research to clinic, to P.I.).We also thank the generous contribution of Banca Intesa San Paolo, and AMAF Monza ONLUS and AIRCS for the unrestricted research funding.

\section{Author contributions}

A.M. and C.G. conceived the study in March 2021 and catalyzed the interaction between different Institutions; C.G., E.V. and B.B. supervised the development of the effort; M.S. and 
medRxiv preprint doi: https://doi.org/10.1101/2021.06.07.21258350; this version posted June 8, 2021. The copyright holder for this preprint

(which was not certified by peer review) is the author/funder, who has granted medRxiv a license to display the preprint in perpetuity.

All rights reserved. No reuse allowed without permission.

378 I.P. conducted the core experimental work related to binding, antiviral activity and

379 Complement activation. The genetic analysis was conducted by E.M.P. supervised by S.D.

380 and R.A.; A.D. performed the imaging analysis; M.P., L.V., M.M and A.C. performed SPR

381 analysis and modeling; S.N.M. performed the bioinformatic analysis; M.G.U., R.R., P.I.

382 provided essential tools and material; F.S., Ma.S., D.C., P.G., N.P., V.C. N.C., N.M.

383 conducted complementary experiments.

384

385 Declaration of interests

386 A.M., C.G. and B.B. are inventors of a patent (EP20182181) on PTX3 and obtain royalties on

387 related reagents; A.M., C.G., B.B. and E.V. are inventors of a patent (102021000002738) on

388 MBL. The other authors declare no competing interests.

389

390 
medRxiv preprint doi: https://doi.org/10.1101/2021.06.07.21258350; this version posted June 8, 2021. The copyright holder for this preprint (which was not certified by peer review) is the author/funder, who has granted medRxiv a license to display the preprint in perpetuity.

\section{$391 \quad$ Figures}

A

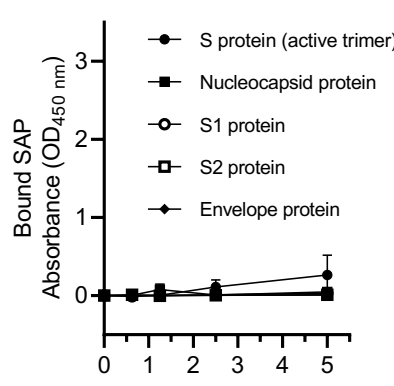

B

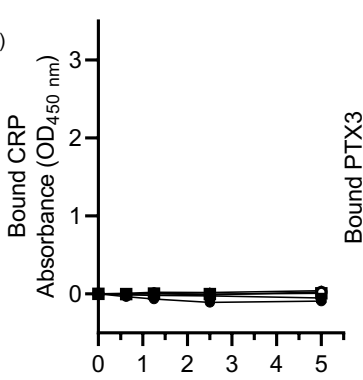

SARS-CoV-2 proteins (pmol/well)
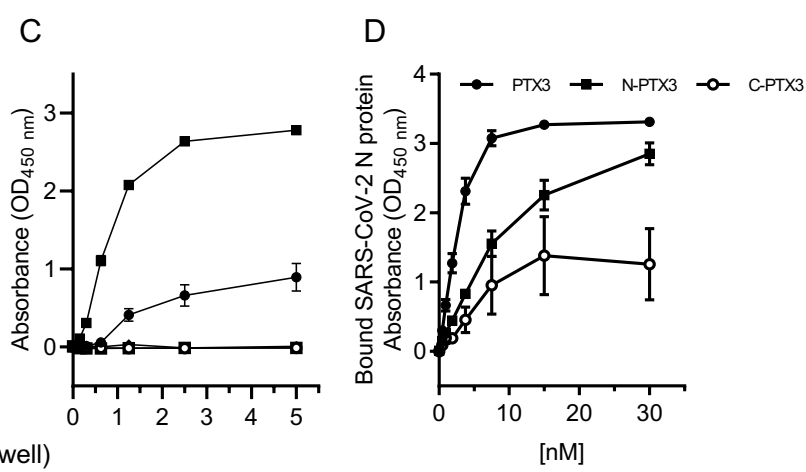

392

393 Figure 1. Interaction between pentraxins and SARS-CoV-2 proteins. (A-C) Recombinant

394 HiS Tag SARS-CoV-2 proteins were immobilized on 96-well Nickel coated plates at different concentrations. Fixed concentrations of SAP (A), CRP (B) and PTX3 (C) were incubated over

396 the captured viral proteins. Bound pentraxins were detected by ELISA with specific primary

397 antibodies. (D) Full length PTX3 or its N- or C-terminal domains were captured on 96-well

398 plates. Biotinylated SARS-CoV-2 Nucleocapsid protein was incubated at different 399 concentrations. Bound nucleocapsid was detected by ELISA using HRP-conjugated 400 streptavidin. All data are presented as mean \pm SEM of two independent experiments performed 401 in duplicate $(n=4)$. 
medRxiv preprint doi: https://doi.org/10.1101/2021.06.07.21258350; this version posted June 8, 2021. The copyright holder for this preprint (which was not certified by peer review) is the author/funder, who has granted medRxiv a license to display the preprint in perpetuity.

A

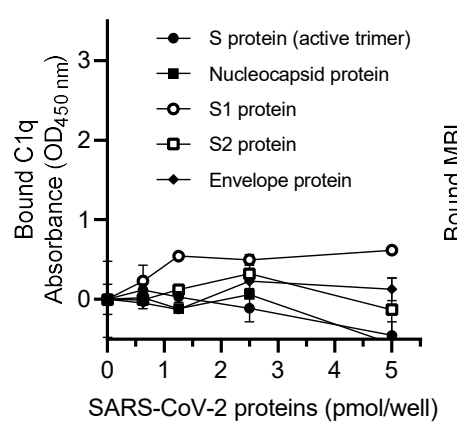

D

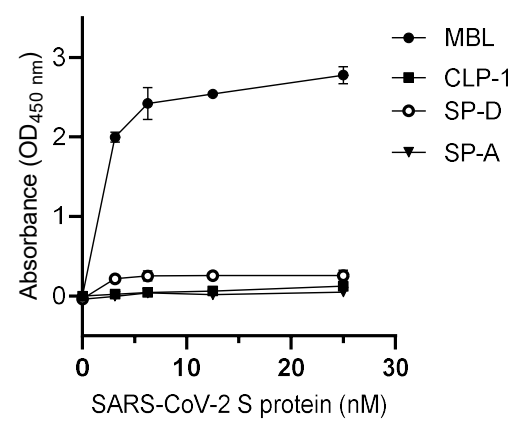

$\mathrm{F}$

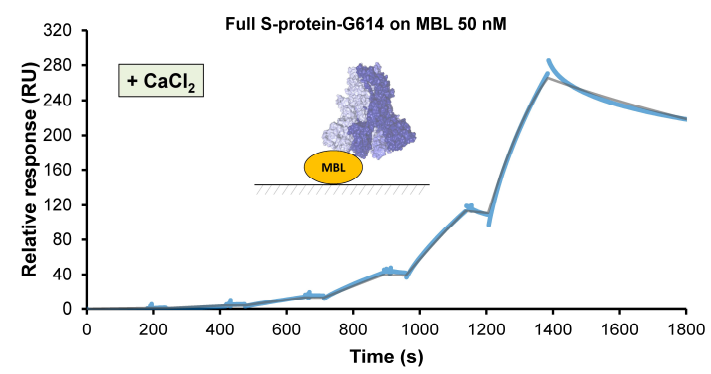

B

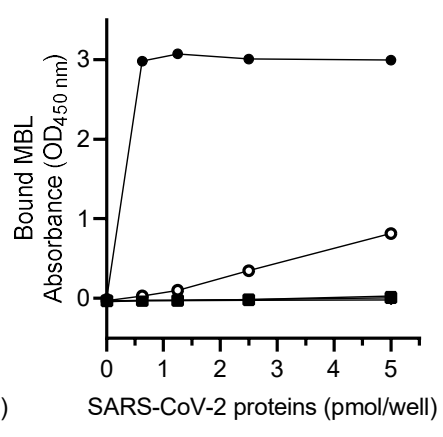

E
C

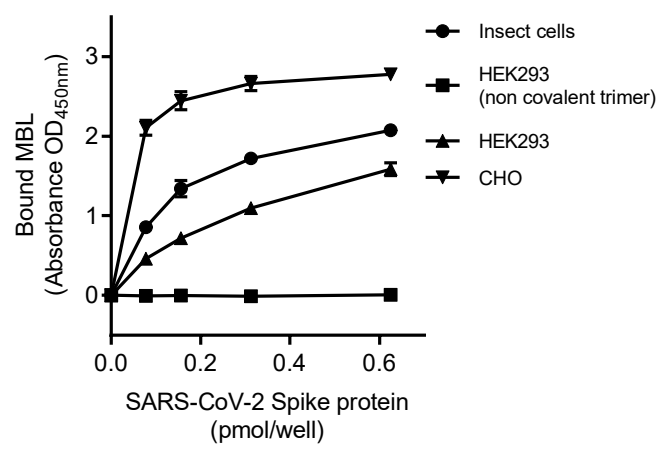

403

404

Figure 2. Interaction of C1q, MBL, ficolins and surfactant proteins with SARS-

405

CoV-2 proteins. (A-C) Recombinant HiS Tag SARS-CoV-2 proteins were immobilized on

406

96-well Nickel coated plates at different concentrations. Fixed concentrations of C1q (A), or

407

MBL (B) were incubated over the captured viral proteins. In (C), recombinant SARS-CoV-2 S

408

proteins tested were expressed in different cell types. MBL $(2 \mu \mathrm{g} / \mathrm{mL}-6.7 \mathrm{nM})$ was incubated

409

over the captured viral proteins. A-C: Bound proteins were detected by ELISA with specific

410 primary antibodies. All data are presented as mean \pm SEM of two independent experiments

411 performed in duplicate (n=4). (D) MBL-, CLP-1-, SP-D-, SP-A- or (E) Ficolin-1-, Ficolin-2- 
medRxiv preprint doi: https://doi.org/10.1101/2021.06.07.21258350; this version posted June 8, 2021. The copyright holder for this preprint (which was not certified by peer review) is the author/funder, who has granted medRxiv a license to display the preprint in perpetuity. All rights reserved. No reuse allowed without permission.

412 and Ficolin-3-coated plates were incubated with various concentrations of biotinylated SARS-

413 CoV-2 S protein. D-E: Bound S protein was detected by ELISA with HRP-conjugated

414 streptavidin (mean \pm SEM of two independent experiments in duplicate, $n=4)$. (F) SPR shows

415 binding of recombinant full Spike protein trimer to immobilized MBL ( $\mathrm{K}_{\mathrm{D}}=34 \mathrm{nM}$, left). No

416 binding is detected in the absence of $\mathrm{CaCl}_{2}$ (right).

417 
medRxiv preprint doi: https://doi.org/10.1101/2021.06.07.21258350; this version posted June 8, 2021. The copyright holder for this preprint (which was not certified by peer review) is the author/funder, who has granted medRxiv a license to display the preprint in perpetuity.

A

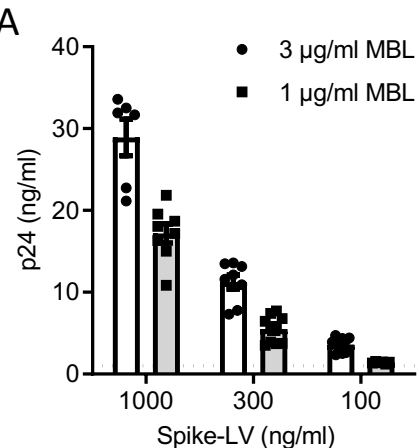

C

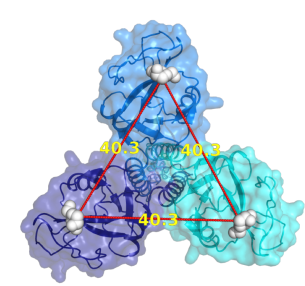

D

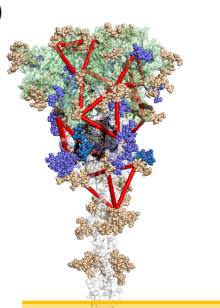

B

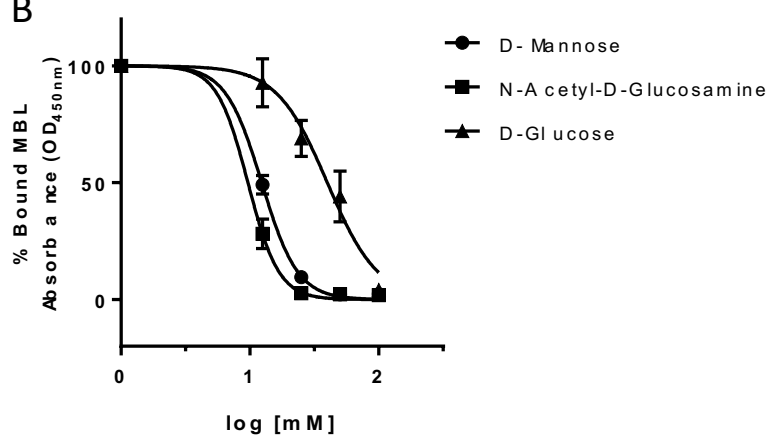

E

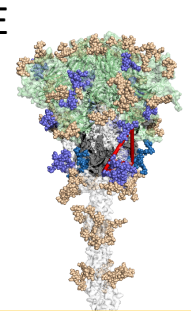

$\mathrm{F}$

G
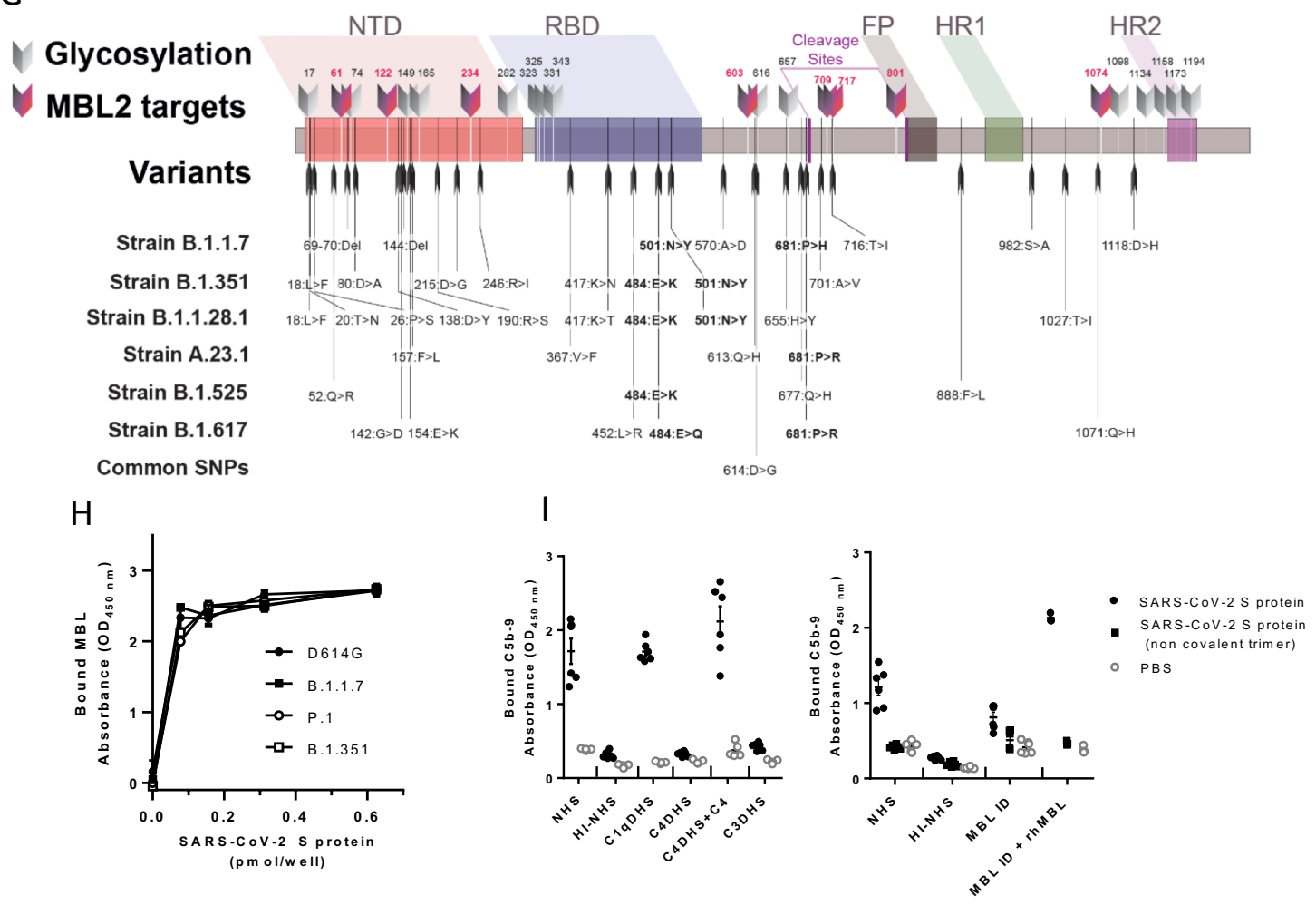

Figure 3. Interaction of $\mathrm{MBL}$ with SARS-CoV-2 $\mathrm{S}$ protein through its

420 Carbohydrate Recognition Domain (CRD). (A) MBL-coated plates were incubated with

421 different concentrations of viral particles of SARS-CoV-2 Spike protein (Spike-LV) or VSV- 
medRxiv preprint doi: https://doi.org/10.1101/2021.06.07.21258350; this version posted June 8, 2021. The copyright holder for this preprint (which was not certified by peer review) is the author/funder, who has granted medRxiv a license to display the preprint in perpetuity. All rights reserved. No reuse allowed without permission.

g pseudotyped on a lentivirus vector. After lysis, bound pseudovirus was quantified by measuring the released p24 core protein by ELISA. Dotted line represents p24 levels measured using the highest concentration of VSV-g pseudotyped lentivirus. Data are represented as mean \pm SEM of two independent experiments $(\mathrm{n}=6-10)$. (B) Biotinylated SARS-CoV-2 S protein was captured on Neutravidin coated plates. MBL $(0.25 \mu \mathrm{g} / \mathrm{mL})$ was incubated over S protein, alone or in the presence of different concentrations of D-mannose or $\mathrm{N}$-acetyl-glucosamine or D-glucose. Binding of free MBL was detected by ELISA. Data are presented as percentage of bound MBL (mean \pm SEM of two independent experiments, $n=4)$. (C) Trimeric MBL2 model shows the distance of approximately $40 \AA$ between mannose-binding sites. MBL2 subunits are represented in transparent surface and cartoon, colored in cyan, blue, and dark blue; mannose molecules are represented in white spheres; (D) 14 mannose-binding sites, represented as red triangles, imposed onto Spike protein. Spike is represented in transparent surface and cartoon, where S1 region (1-685) is colored in green, beginning of S2 region (686-815) is colored in black, and S2' region is colored in white. (E) Putative binding site of MBL2. Pose with the highest site-specific probability to be glycosylated with oligomannose; (F) Spike-MBL2 complex. Glycosylation sites are colored according to the oligomannose glycosylation probability. Gold $<60 \%$. Purple $>80 \%$ up until S2' region. Blue $>80 \%$ in the S2' region. (G) Schematic representation of glycosylation sites and nucleotide substitutions in the variant strains identified to date. The 8 glycosylation sites containing oligomannose-types glycans, which are potential targets of MBL, are evidenced. SNPs common to all variants are in bold. NTD: N terminal domain; RBD: receptor binding domain; FP: fusion peptide; HR1 and 2: heptad repeat 1 and 2; cleavage sites are reported. (H) Binding of MBL to SARS-CoV-2 S protein variants: recombinant SARS-CoV-2 S protein (D614G), B.1.1.7, P.1, and B.1.351 variants were captured onto a Nickel coated plate at different concentrations. MBL $(1 \mu \mathrm{g} / \mathrm{mL}$ $-3.4 \mathrm{nM}$ ) was incubated over the captured viral proteins. Data are represented as mean $\pm \mathrm{SEM}$, 
medRxiv preprint doi: https://doi.org/10.1101/2021.06.07.21258350; this version posted June 8, 2021. The copyright holder for this preprint (which was not certified by peer review) is the author/funder, who has granted medRxiv a license to display the preprint in perpetuity. All rights reserved. No reuse allowed without permission.

$447 \mathrm{n}=3$ replicates. One representative experiment out of two performed is shown for B.1.1.7. For

448 the other variants, one experiment was performed. (I) MAC (C5b-9) deposition on SARS-CoV-

4492 Spike protein-coated plates. The assay was performed in the presence of $10 \%$ normal human

450 serum (NHS), C1qDHS, C4DHS, C4DHS reconstituted with C4, C3DHS, MBL-ID serum,

451 MBL-ID serum reconstituted with rhMBL. Mean \pm SEM of two independent experiments, 452 performed in triplicate $(n=6)$.

453 
medRxiv preprint doi: https://doi.org/10.1101/2021.06.07.21258350; this version posted June 8, 2021. The copyright holder for this preprint (which was not certified by peer review) is the author/funder, who has granted medRxiv a license to display the preprint in perpetuity.

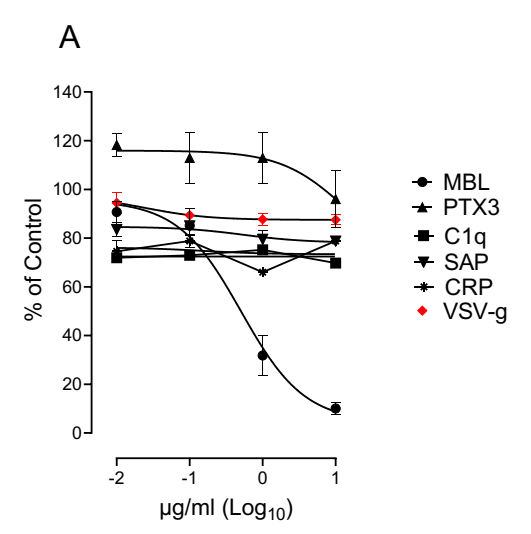

B.1.1.7

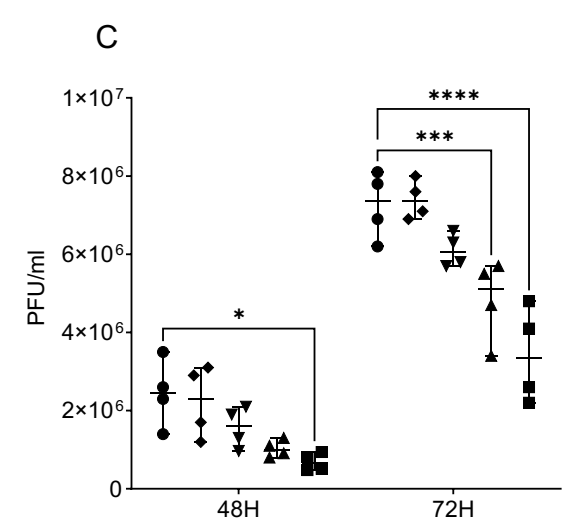

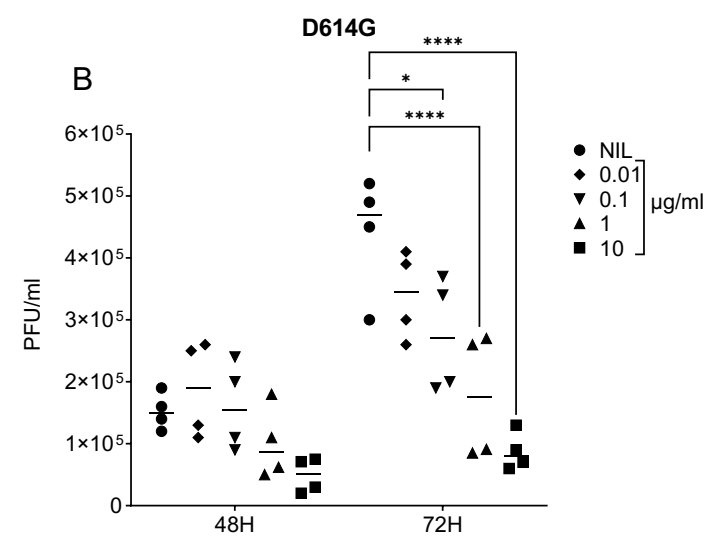

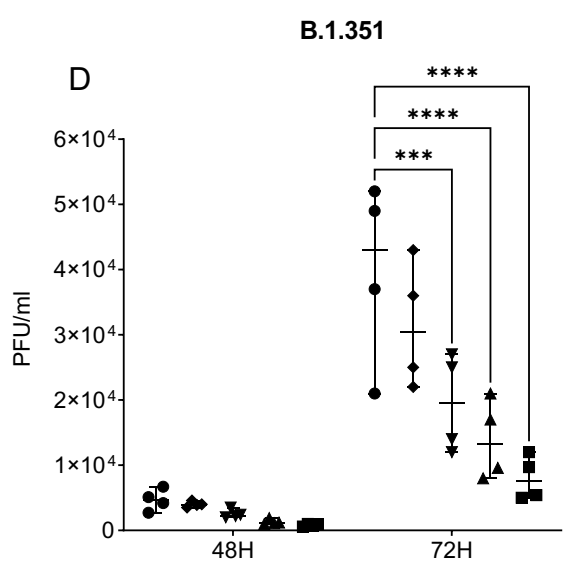

454

455

456

457

458

459

460

461

462

463

464

465

466

Figure 4. Inhibition of SARS-CoV-2 infection by MBL. (A) Entry of lentiviral particles pseudotyped with SARS-CoV-2 Spike protein in 293T cells overexpressing ACE2 in the presence of ten-fold serial dilutions of humoral innate immunity PRMs (from 0.01 to 10 $\mu \mathrm{g} / \mathrm{ml})$. As control, entry of lentiviral particles pseudotyped with the VSV-g glycoprotein was tested in parallel in the presence of MBL. Percentage of control was calculated as ratio of GFPpositive cells in the presence of humoral PRMs and the GFF-positive cells in the absence of humoral PRMs. Data are means \pm SEM of three independent experiments in triplicates with the curves representing a three-parameter dose response model. (B-D) Inhibition of the infectivity of the D614G (isolate EPI_ISL_413489) (B), B.1.1.7 (C) and B.1.351 (D) SARSCoV-2 variants by MBL in Calu-3 cells. SARS-CoV-2 (MOI=1) and Calu-3 cells were preincubated in complete medium containing different concentrations of MBL (0.01-10 $\mu \mathrm{g} / \mathrm{mL}-0.034-34 \mathrm{nM}$ ) before infection. After 48 and $72 \mathrm{~h}$, the infectivity of SARS-CoV-2 
medRxiv preprint doi: https://doi.org/10.1101/2021.06.07.21258350; this version posted June 8, 2021. The copyright holder for this preprint (which was not certified by peer review) is the author/funder, who has granted medRxiv a license to display the preprint in perpetuity. All rights reserved. No reuse allowed without permission.

467 present in cell culture supernatants was determined by a plaque-forming assay in Vero cells.

468 NIL: no MBL. Mean values of two (B) or one (C, D) experiments in duplicate cell culture are

469 shown. $* * * *$ p value $<0.0001, * * *$ p value $<0.001, * *$ p value $<0.01$ as determined by two-way

470 ANOVA with Bonferroni’s correction.

471 
medRxiv preprint doi: https://doi.org/10.1101/2021.06.07.21258350; this version posted June 8, 2021. The copyright holder for this preprint (which was not certified by peer review) is the author/funder, who has granted medRxiv a license to display the preprint in perpetuity. All rights reserved. No reuse allowed without permission.
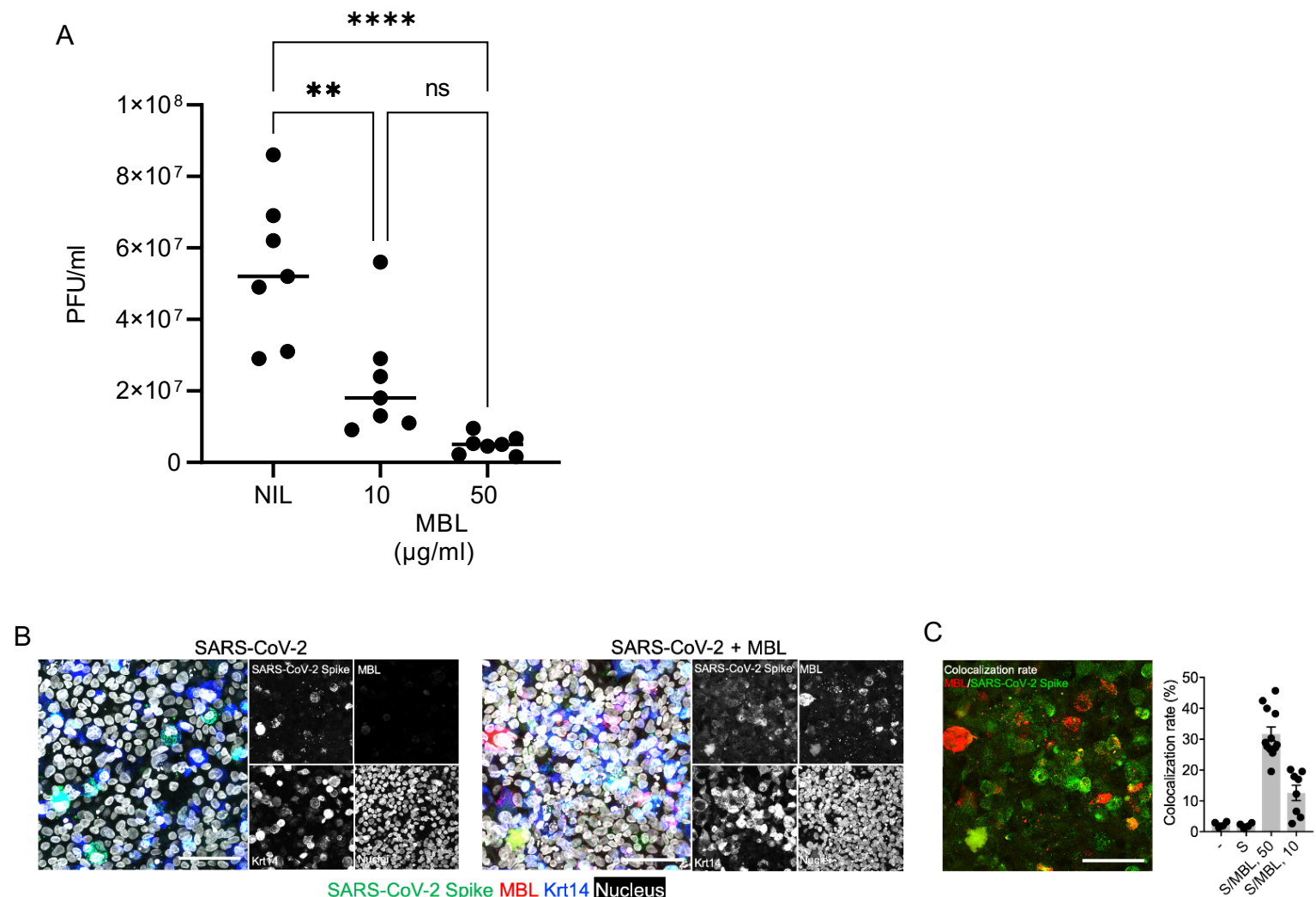

D

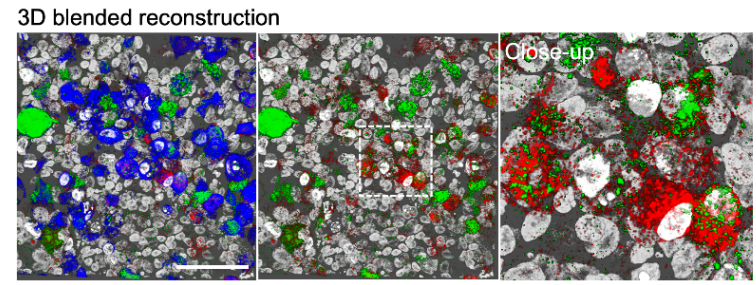

SARS-CoV-2 Spike MBL Krt14 Nucleus
E

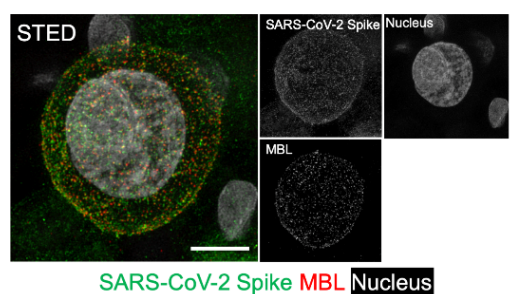

474 Figure 5. Inhibition by MBL of SARS-CoV-2 infection of primary respiratory cells. (A)

SARS-CoV-2 production at the HBEC apical surface at $72 \mathrm{~h} \mathrm{PI}$, in the presence of 10 or 50 $\mu \mathrm{g} / \mathrm{ml}$ (34 or $170 \mathrm{nM}$ ) MBL. Mean values of three experiments in triplicate (2 donors) or single

477 (1 donor) cell cultures are shown. A: $p$ values were determined by one-way ANOVA with

478 Bonferroni's correction. ****: p value $<0.0001$, **: p value $<0.01$. (B-E) Colocalization of

479 SARS-CoV-2 S protein and MBL in infected HBEC. (B), Confocal analysis of the localization

480 of SARS-CoV-2 S protein (green), MBL (red) in HBEC cultures infected by SARS-CoV-2 in

481 presence or not of MBL $(50 \mu \mathrm{g} / \mathrm{ml}-170 \mathrm{nM})$. Left panels, merged images of fluorescence 
medRxiv preprint doi: https://doi.org/10.1101/2021.06.07.21258350; this version posted June 8,2021 . The copyright holder for this preprint (which was not certified by peer review) is the author/funder, who has granted medRxiv a license to display the preprint in perpetuity. All rights reserved. No reuse allowed without permission.

482 signals; right panels, single signals extracted. Representative MIP images of 4-12 Z- stacks 483 acquired in tiling modality are shown. Bar, $30 \mu \mathrm{m}$. (C) Left panel: extracted signals of SARS484 CoV-2 S protein and MBL of (B). Right panel: colocalization rate between SARS-CoV-2 S 485 protein and MBL (10 or $50 \mu \mathrm{g} / \mathrm{ml}-34$ or $170 \mathrm{nM}$ ). Each spot corresponds to a single $X Y Z$ 486 image presented as MIP. Mean \pm SE. (D) 3D rendering of B right panel, showing a blended 487 reconstruction of the localization between SARS-CoV-2 S protein and MBL in HBEC cultures. 488 Left panel, contribution of merged signals. Bar, $30 \mu \mathrm{m}$. Middle panel, extracted image of signal 489 of SARS-CoV-2 S protein and MBL. Right panel, close-up image that refers to the area dashed 490 in white. (E) STED analysis of the localization of SARS-CoV-2 S protein and MBL in HBEC. 491 Left panel, merged signals of SARS-CoV-2 S protein and MBL and nucleus; right, single 492 signals extracted. Bar, $3 \mu \mathrm{m}$. 
medRxiv preprint doi: https://doi.org/10.1101/2021.06.07.21258350; this version posted June 8,2021 . The copyright holder for this preprint (which was not certified by peer review) is the author/funder, who has granted medRxiv a license to display the preprint in perpetuity.

A

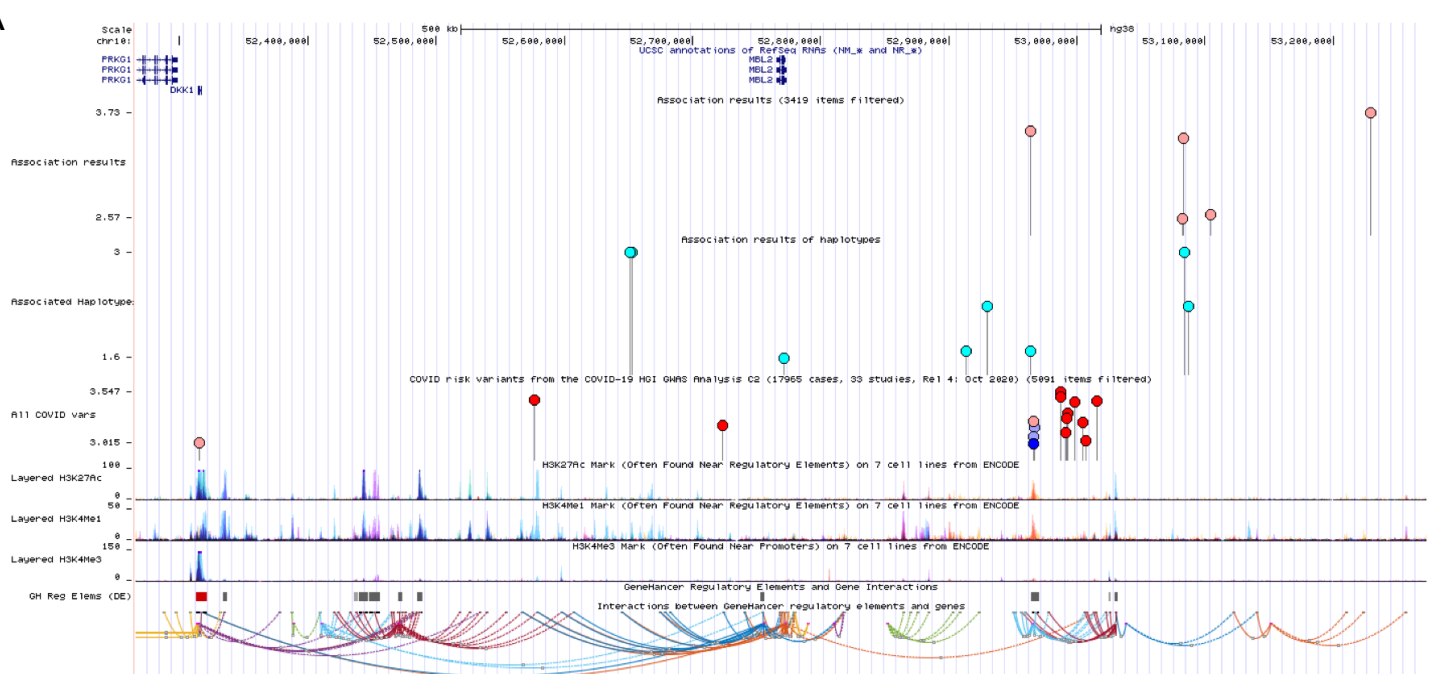

B

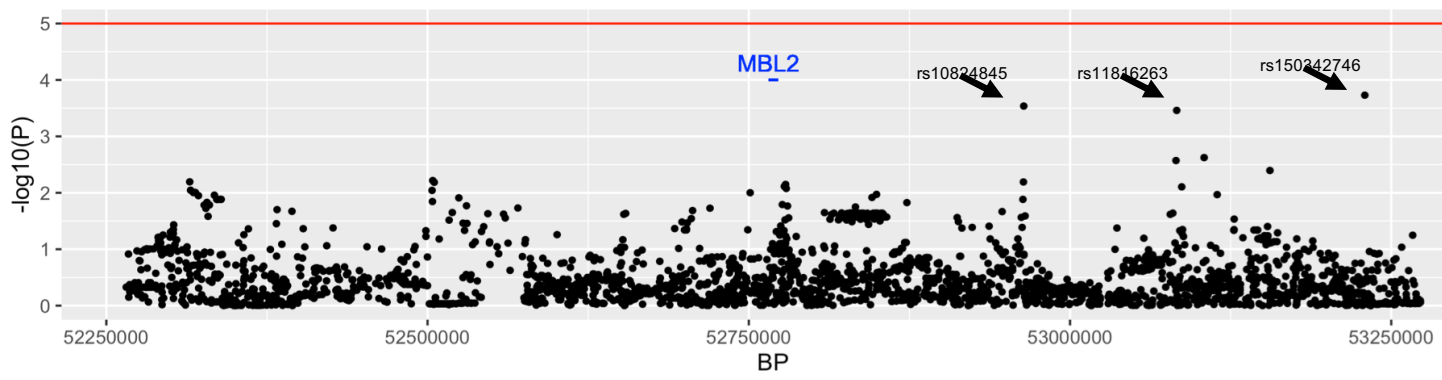

496 Figure 6: The $M B L 2$ locus: structure and main association signals with severe COVID-

49719.

498 (A) A screenshot from the UCSC Genome browser (http://genome.ucsc.edu/; release Dec.

499 2013, GRCh38/hg38) specifically highlighting the 1-Mb region surrounding the $M B L 2$ gene is

500 shown. The panel reports, in order, the following tracks: i) the ruler with the scale at the

501 genomic level; ii) chromosome 10 nucleotide numbering; iii) the UCSC RefSeq track; iv)

502 COVID-19 risk variants from our study (lollipops show only signals at $\mathrm{P}<3^{*} 10^{-3}$ ); v) COVID-

50319 risk haplotypes, marked by the tagging SNP, from our study (lollipops show all haplotypes

504 reported in Table 1B and 1D); vi) COVID-19 risk variants from the COVID-19 HGI GWAS

505 Analysis C2 (17,965 cases, 33 studies, Release 4: October 2020); vii) ENCODE data 
medRxiv preprint doi: https://doi.org/10.1101/2021.06.07.21258350; this version posted June 8, 2021. The copyright holder for this preprint (which was not certified by peer review) is the author/funder, who has granted medRxiv a license to display the preprint in perpetuity. All rights reserved. No reuse allowed without permission.

506 (https://www.encodeproject.org/) for H3K27Ac, H3K4Me1, H3K4Me3 histone modifications

507 marks, all derived from 7 cell lines; viii) the GeneHancer regulatory elements track.

508 (B) The Manhattan plot of the single-SNP association analysis is reported. The horizontal line 509 represents the suggestive $\mathrm{P}=5 * 10^{-5}$ significance level. SNPs showing lowest $\mathrm{P}$ value signals 510 are indicated by an arrow. Bonferroni threshold for significance corresponds to $\mathrm{P}<1.5^{*} 10^{-5}$.

511

512 
medRxiv preprint doi: https://doi.org/10.1101/2021.06.07.21258350; this version posted June 8, 2021. The copyright holder for this preprint (which was not certified by peer review) is the author/funder, who has granted medRxiv a license to display the preprint in perpetuity.

513 Table 1. Association analysis results

514 A. Candidate SNP association analysis

\begin{tabular}{llllllllll}
\hline SNP* & rsID & Variation & A1 & $\begin{array}{l}\text { MAF } \\
\text { cases }\end{array}$ & $\begin{array}{l}\text { MAF } \\
\text { controls }\end{array}$ & OR & 95\%CI & P* & $\begin{array}{l}\text { Direction } \\
\text { (A1) ** }\end{array}$ \\
\hline chr10:52771466:C:T & rs1800451 & p.Gly57Glu & T & 0.017 & 0.021 & 0.814 & $\begin{array}{l}0.39- \\
1.72\end{array}$ & 0.588 & $\begin{array}{l}\text { Lowers } \\
\text { MBL2 levels }\end{array}$ \\
\hline chr10:52771475:C:T & rs1800450 & p.Gly54Asp & T & 0.017 & 0.15 & 1.070 & $\begin{array}{l}0.83- \\
1.39\end{array}$ & 0.609 & $\begin{array}{l}\text { Lowers } \\
\text { MBL2 levels }\end{array}$ \\
\hline chr10:52771482:G:A & rs5030737 & p.Arg52Cys & A & 0.077 & 0.06 & 1.434 & $\begin{array}{l}1.00- \\
2.05\end{array}$ & 0.049 & $\begin{array}{l}\text { Lowers } \\
\text { MBL2 levels }\end{array}$ \\
\hline chr10:52771701:G:A & rs7095891 & $\begin{array}{l}\text { Promoter } \\
\text { region }\end{array}$ & A & 0.221 & 0.243 & 0.827 & $\begin{array}{l}0.66- \\
1.04\end{array}$ & 0.104 & - \\
\hline chr10:52771925:G:C & rs7096206 & $\begin{array}{l}\text { Promoter } \\
\text { eQTL in liver } \\
\left(\begin{array}{l}\text { P=1.7*10-17) } \\
\text { M }\end{array}\right.\end{array}$ & G & 0.215 & 0.205 & 1.201 & $\begin{array}{l}0.96- \\
1.51\end{array}$ & 0.113 & $\begin{array}{l}\text { Lowers MBL2 } \\
\text { levels }\end{array}$ \\
\hline chr10:52772254:G:C & rs11003125 & $\begin{array}{l}\text { Promoter } \\
\text { eQTL in liver } \\
\left(\mathrm{P}=9.1 * 10^{-6}\right)\end{array}$ & $\mathrm{C}$ & 0.342 & 0.364 & 0.886 & $\begin{array}{l}0.73- \\
1.09\end{array}$ & 0.236 & $\begin{array}{l}\text { Increases } \\
\text { MBL2 levels }\end{array}$ \\
\hline
\end{tabular}

$515 *$ Bonferroni threshold for significance is $\mathrm{P}<0.008$.

$516 * *$ Direction derived from either the literature or the GTEx database (The Genotype-Tissue

517 Expression database; https://www.gtexportal.org/home/).

518

519 B. Haplotype analysis for candidate SNPs

$520 \quad$ (rs1800451|rs1800450|rs5030737|rs7095891|rs7096206|rs11003125)

\begin{tabular}{llllll}
\hline Haplotype & Frequency in cases & Frequency in controls & OR & CI & P* \\
\hline CCAGCC & 0.075 & 0.060 & 1.380 & $1.000-1.903$ & 0.078 \\
\hline CCGGCC & 0.267 & 0.304 & 0.785 & $0.651-0.946$ & 0.025 \\
\hline CCGGGG & 0.216 & 0.205 & 1.190 & $0.971-1.458$ & 0.130 \\
\hline TCGACG & 0.017 & 0.0210 & 0.870 & $0.458-1.652$ & 0.704 \\
\hline CCGACG & 0.205 & 0.222 & 0.833 & $0.678-1.023$ & 0.121 \\
\hline CTGGCG & 0.166 & 0.150 & 1.090 & $0.870-1.366$ & 0.501 \\
\hline CCGGCG & 0.054 & 0.038 & 1.500 & $1.026-2.192$ & 0.056 \\
\hline
\end{tabular}

* Bonferroni threshold for significance is $\mathrm{P}<0.05$.

C. Locus-wide association analysis (SNPs with $\mathbf{P}<0.0050$ are shown)

\begin{tabular}{llllllll}
\hline SNP & rsID & A1 & MAF cases & MAF controls & OR & 95\%CI & P* \\
\hline chr10:53229424:C:T & rs150342746 & T & 0.026 & 0.008 & 3.474 & $1.808-6.676$ & $1.86 * 10^{-4}$ \\
\hline chr10:52963964:G:A & rs10824845 & A & 0.124 & 0.072 & 1.762 & $1.297-2.393$ & $2.91 * 10^{-4}$ \\
\hline chr10:53083059:C:A & rs11816263 & A & 0.386 & 0.315 & 1.422 & $1.173-1.725$ & $3.47 * 10^{-4}$ \\
\hline chr10:53104393:A:G & rs74974397 & G & 0.071 & 0.041 & 1.813 & $1.235-2.661$ & 0.0024 \\
\hline chr10:53082503:A:AT & rs71032688 & A & 0.258 & 0.191 & 1.415 & $1.128-1.776$ & 0.0025 \\
\hline chr10:53155596:C:T & rs117108247 & T & 0.069 & 0.042 & 1.750 & $1.195-2.561$ & 0.0040 \\
\hline
\end{tabular}


medRxiv preprint doi: https://doi.org/10.1101/2021.06.07.21258350; this version posted June 8, 2021. The copyright holder for this preprint (which was not certified by peer review) is the author/funder, who has granted medRxiv a license to display the preprint in perpetuity. All rights reserved. No reuse allowed without permission.

D. Locus-wide haplotype analysis

\begin{tabular}{|c|c|c|c|c|c|c|c|}
\hline Haplotype & $\begin{array}{l}\text { Frequency in } \\
\text { cases }\end{array}$ & $\begin{array}{l}\text { Frequency in } \\
\text { controls }\end{array}$ & OR & CI & $\mathbf{P}$ & $\begin{array}{l}\mathbf{P} \\
\text { permutation* }\end{array}$ & SNPs** \\
\hline ATCGCAA & 0.006 & 0.043 & 0.133 & $0.049-0.36$ & $2.26^{*} 10^{-7}$ & $9.99 * 10^{-4}$ & $\begin{array}{l}6 \text { SNPs, } \\
\text { rs11344513|rs7071467 }\end{array}$ \\
\hline $\mathrm{CCC}$ & 0.005 & 0.073 & 0.058 & $0.019-0.182$ & $3.12 * 10^{-16}$ & $9.99 * 10^{-4}$ & $\begin{array}{l}\text { SNPs, } \\
\text { rs17662822|rs1159798| } \\
\text { rs1912619 }\end{array}$ \\
\hline TCCCC & 0.000 & 0.021 & $<1.00$ & $\mathrm{nc}$ & $1.17 * 10^{-5}$ & 0.019 & $\begin{array}{l}5 \text { SNPs, } \\
\text { rs2204344|rs12218074| } \\
\text { rs80035245|rs79357128| } \\
\text { rs10824836 }\end{array}$ \\
\hline TCAGACC & 0.032 & 0.007 & 4.92 & $2.69-9$ & $2.59 * 10^{-6}$ & $4.99 * 10^{-3}$ & $\begin{array}{l}\text { 5 SNPs, } \\
\text { rs16935439|rs147096903 } \\
\mid \text { rs } 10824839 \mid \text { rs } 11003267 \mid \\
\text { rs11003268 }\end{array}$ \\
\hline TA & 0.122 & 0.069 & 1.876 & $1.435-2.453$ & $1.04 * 10^{-5}$ & 0.018 & $\begin{array}{l}\text { 2 SNPs, } \\
\text { rs10824844|rs10824845 }\end{array}$ \\
\hline $\begin{array}{l}\text { ATCCCCGC } \\
\text { ATTGA } \\
\end{array}$ & 0.000 & 0.040 & $<1.00$ & nc & $3.41 * 10^{-7}$ & $9.99 * 10^{-4}$ & $\begin{array}{l}\text { 9 SNPs, rs57504125| } \\
\text { chr10:5308418:G:A }\end{array}$ \\
\hline $\begin{array}{l}\text { AGATCCCC } \\
\text { GCGCGTGC } \\
\text { AACGGCT }\end{array}$ & 0.237 & 0.170 & 1.509 & $1.235-1.844$ & $3.28 * 10^{-6}$ & $4.99 * 10^{-3}$ & $\begin{array}{l}24 \text { SNPs, } \\
\text { rs71032688|rs7092597 }\end{array}$ \\
\hline
\end{tabular}

* P Value as calculated after performing 1,000 permutations to correct for multiple testing. ** The number of SNPs composing the haplotype is indicated. All the SNPs forming the haplotype are shown for short haplotypes (including max 5 SNPs). For more complex haplotypes (including $>5$ SNPs) only the first and the last SNPs are indicated.

\section{E. Meta-analysis for the rs10824845 polymorphism}

\begin{tabular}{llllll}
\hline Cohort & $\begin{array}{l}\text { Cases (A1/A2 } \\
\text { alleles) }\end{array}$ & $\begin{array}{l}\text { Controls (A1/A2 } \\
\text { alleles) }\end{array}$ & OR & $\mathbf{9 5 \% C I}$ & P \\
\hline Italian cohort & $82 / 582$ & $241 / 3,095$ & 1.81 & $1.392-2.353$ & $9.57^{*} 10^{-6}$ \\
\hline GHS cohort & $180 / 1,558$ & $18,979 / 205,845$ & 1.20 & $1.024-1.396$ & 0.023 \\
\hline Summary & & & 1.32 & $1.149-1.520$ & $9.12^{*} 10^{-5}$ \\
\hline
\end{tabular}

540 In all sub-tables the SNP column is in the format chromosome:position:reference 541 allele:alternative allele. The position refers to hg38 version of the genome.

$542 \mathrm{~A} 1=$ minor allele; $\mathrm{A} 2=$ major allele; $\mathrm{CI}=$ confidence interval; $\mathrm{MAF}=$ minor allele frequency; $543 \mathrm{nc}=$ not calculated; $\mathrm{OR}=$ odds ratio; $\mathrm{rsID}=$ reference sequence identification number; 
medRxiv preprint doi: https://doi.org/10.1101/2021.06.07.21258350; this version posted June 8, 2021. The copyright holder for this preprint (which was not certified by peer review) is the author/funder, who has granted medRxiv a license to display the preprint in perpetuity.

Methods

\section{Recombinant proteins and Antibodies} are listed in Supplementary Table 1. Recombinant human PTX3 and its domains from CHO cells were produced in house, as previously described (Bottazzi et al., 1997). Recombinant human Surfactant Protein-A (SP-A) was from Origene. Recombinant human MBL, Collectin-

Biotechne. Purified human C1q was from Complement Technology, purified CRP was from Millipore and purified SAP was purchased from Abcam. Rabbit anti-PTX3 antibody was produced in house (Bottazzi et al., 1997), rabbit anti-MBL Ab was purchased from Abcam.

Anti-C1q polyclonal antibody was purchased from Dako. Anti-CRP and anti-SAP antibodies were from Merck.

\section{Binding of Humoral Pattern Recognition Molecules to SARS-CoV-2 proteins}

Recombinant His-Tag SARS-CoV-2 proteins were immobilized at different concentrations (ranging from 6.25 to $50 \mathrm{pmol} / \mathrm{mL}$ ) on 96-well Nickel coated plates (Thermo

563 Fisher Scientific) for $1 \mathrm{~h}$ at room temperature. Plates were then blocked for $2 \mathrm{~h}$ at $37^{\circ} \mathrm{C}$ with $200 \mu \mathrm{L}$ of $2 \%$ BSA diluted in $10 \mathrm{mM}$ Tris- $\mathrm{HCl}$ buffer, $\mathrm{pH} 7.5$, containing $150 \mathrm{mM} \mathrm{NaCl}, 2$ $\mathrm{mM} \mathrm{CaCl} 2$ and $0.1 \%$ Tween-20 (TBST-Ca $\left.{ }^{2+}\right)$. Following blocking, plates were washed three times with TBST-Ca ${ }^{2+}$ and incubated for $1 \mathrm{~h}$ at $37^{\circ} \mathrm{C}$ with $100 \mu \mathrm{L}$ PTX3 $(4 \mu \mathrm{g} / \mathrm{mL}-12 \mathrm{nM}$ in

567 TBST-Ca $\left.{ }^{2+}\right)$, MBL $\left(1-2 \mu \mathrm{g} / \mathrm{mL}-3.4-6.7 \mathrm{nM}\right.$ in TBST-Ca $\left.{ }^{2+}\right), \mathrm{C} 1 \mathrm{q}(4 \mu \mathrm{g} / \mathrm{mL}-10 \mathrm{nM}$ in TBST-

$\left.568 \mathrm{Ca}^{2+}\right)$, CRP $\left(3 \mu \mathrm{g} / \mathrm{mL}-25 \mathrm{nM}\right.$ in TBST-Ca $\left.{ }^{2+}\right)$ and SAP $\left(4 \mu \mathrm{g} / \mathrm{mL}-32 \mathrm{nM}\right.$ in TBST-Ca $\left.{ }^{2+}\right)$.

569 After washes, plates were incubated for $1 \mathrm{~h}$ at $37^{\circ} \mathrm{C}$ with specific primary antibodies, followed by the corresponding HRP-conjugated secondary antibodies. Both primary and secondary

571 antibodies were diluted in TBST- $\mathrm{Ca}^{2+}$ buffer. After development with the chromogenic 572 substrate 3,3',5,5'-tetramethylbenzidine (TMB, Thermo Fisher Scientific, USA), binding was 
medRxiv preprint doi: https://doi.org/10.1101/2021.06.07.21258350; this version posted June 8, 2021. The copyright holder for this preprint (which was not certified by peer review) is the author/funder, who has granted medRxiv a license to display the preprint in perpetuity. All rights reserved. No reuse allowed without permission.

detected by absorbance reading at $450 \mathrm{~nm}$ on a Spectrostar Nano Microplate Reader (BMG Labtech, Germany). Values from blank wells were subtracted from those recorded at sample wells.

In another set of experiments, $100 \mu \mathrm{L}$ of $2 \mu \mathrm{g} / \mathrm{mL}$ rhMBL (6.7 nM), CLP-1 (6.7 nM), Ficolin-1 (5 nM), Ficolin-2 (5 nM), and Ficolin-3 (3 nM), SP-A (3 nM) or SP-D (3.4 nM) in PBS were immobilized on 96-well Nunc Maxisorp Immunoplates (Costar, USA) overnight at $4^{\circ} \mathrm{C}$. Plates were blocked with $200 \mu \mathrm{L}$ of $2 \%$ BSA-TBST-Ca ${ }^{2+}$ for $2 \mathrm{~h}$ at $37^{\circ} \mathrm{C}$. After washes, $100 \mu \mathrm{L}$ of biotinylated SARS-CoV-2 S protein was added at different concentrations to the plates for $1 \mathrm{~h}$ at $37^{\circ} \mathrm{C}$. Following washes, HRP-conjugated streptavidin $(1: 10000$, Biospa) was incubated for $1 \mathrm{~h}$ at $37^{\circ} \mathrm{C}$. Specific binding was detected by TMB development, as described above.

For competition-based experiments, biotinylated SARS-CoV-2 S protein was captured on 96-wells Neutravidin coated plates for $1 \mathrm{~h}$ at $37^{\circ} \mathrm{C}$. Plates were then incubated for $1 \mathrm{~h}$ at $37^{\circ} \mathrm{C}$ with $100 \mu \mathrm{L}$ rhMBL $(0.25 \mu \mathrm{g} / \mathrm{mL}-0.83 \mathrm{nM})$ alone or in the presence of various concentrations of D-mannose or N-acetyl-glucosamine, or D-glucose (Sigma Aldrich). Bound MBL was detected by incubation with rabbit anti-MBL antibody, followed by HRP-conjugated secondary antibody and TMB development, as described above.

For the experiments on the interaction between PTX3 domains and SARS-CoV-2 Nucleocapsid, PTX3 and its recombinant domains were immobilized on the wells of a 96-well Nunc Maxisorp plate. Then, different concentrations of biotinylated SARS-CoV-2 Nucleocapsid protein were added over the captured proteins for $1 \mathrm{~h}$ at $37^{\circ} \mathrm{C}$. Detection of binding was achieved through incubation with HRP-conjugated streptavidin, as detailed above.

\section{Surface plasmon resonance (SPR) studies}

SPR analyses were carried out at $25^{\circ} \mathrm{C}$ on a Biacore $8 \mathrm{~K}$ instrument (GE Healthcare).

MBL was immobilized on the surface of a CM5 sensor chip through standard amine coupling. 
medRxiv preprint doi: https://doi.org/10.1101/2021.06.07.21258350; this version posted June 8, 2021. The copyright holder for this preprint (which was not certified by peer review) is the author/funder, who has granted medRxiv a license to display the preprint in perpetuity. All rights reserved. No reuse allowed without permission.

598 Briefly, after activation of the surface with a mixture of 1-Ethyl-3-(3-dimethylaminopropyl)

599 carbodiimide hydrochloride and N-Hydroxysuccinimide, MBL was diluted at $50 \mathrm{nM}$ in $10 \mathrm{mM}$

600 sodium acetate buffer, $\mathrm{pH} 4.5$ and injected over the surface (flow rate $10 \mu \mathrm{l} / \mathrm{min}$ ). Free activated

601 sites were blocked by flowing $1 \mathrm{M}$ Ethanolamine, $\mathrm{pH}$ 8.5. Final MBL immobilization levels

602 were around 4500 Resonance Units (RU, with $1 \mathrm{RU}=1 \mathrm{pg} / \mathrm{mm}^{2}$ ). A second surface was 603 prepared in parallel with the same procedure, but without any ligand, and used as reference.

604 Recombinant RBD and trimeric Spike were produced in EXPI293 cells and purified as reported

605 (De Gasparo et al., 2021). Increasing concentration of SARS-CoV-2 RBD or Spike protein $606(2.5,7.4,22,67,200$ and $600 \mathrm{nM})$ were injected using a single-cycle kinetics setting at a flow 607 rate of $30 \mu \mathrm{l} / \mathrm{min}$; dissociation was followed for 10 minutes. The running buffer (also used to 608 dilute samples) was $10 \mathrm{mM}$ Tris-buffered saline, $\mathrm{pH} 7.4$, containing $150 \mathrm{mM} \mathrm{NaCl}, 2 \mathrm{mM}$ $609 \mathrm{CaCl}_{2}$ and $0.005 \%$ Tween-20. In another set of experiments, the interaction was analyzed using 610 the running buffer without $\mathrm{CaCl}_{2}$. Analyte responses were corrected for unspecific binding and

611 buffer responses through the use of reference channels. Binding kinetics were determined by

612 fitting of the experimental curves with the Langmuir 1:1 model according to standard 613 procedures; data analyses were performed with Biacore ${ }^{\mathrm{TM}}$ Insight Evaluation Software 614 v2.0.15.12933. In the presence of $\mathrm{CaCl}_{2}$, trimeric Spike bound to $\mathrm{MBL}$ with $\mathrm{K}_{\mathrm{a}}(1 / \mathrm{Ms})=2.1 \mathrm{e}^{+} 4$, $615 \mathrm{~K}_{\mathrm{d}}(1 / \mathrm{s})=7.3 \mathrm{e}^{-4}$ and $\mathrm{K}_{\mathrm{D}}=34 \mathrm{nM}$.

\section{Computational modeling of the MBL2 SARS-CoV-2 Spike interaction}

617 The model of the MBL2 trimer (UniProt(Consortium, 2020) P11226) was created 618 starting from the crystal structure of human mannose binding protein(Sheriff et al., 1994) (PDB 619 code 1HUP). The N-terminus of MBL2 was modeled as collagen, based on the template crystal 620 structure of collagen triple helix model(Berisio et al., 2002) (PDB code 1K6F). The binding 621 site of mannose molecules was determined aligning the MBL2 structure to the crystal structure 
medRxiv preprint doi: https://doi.org/10.1101/2021.06.07.21258350; this version posted June 8, 2021. The copyright holder for this preprint (which was not certified by peer review) is the author/funder, who has granted medRxiv a license to display the preprint in perpetuity.

622 of rat mannose protein $\mathrm{A}(\mathrm{Ng}$ et al., 2002) (PDB code $1 \mathrm{KX} 1)$. Reference distances $(\sim 40 \AA)$

623 between mannose molecules were computed in PYMOL.

624 Putative binding sites of MBL2 were determined identifying all triplets of N-

625 glycosylation sites at a distance between $35 \AA$ and $50 \AA$ in the closed state SARS-CoV-2

626 (Casalino et al., 2020). Distances were computed using the program ALMOST(Fu et al., 2014).

627 Pseudotyped virus production

628 Human embryonic kidney $293 \mathrm{~T}$ cells were transfected with a lentiviral vector 629 expressing the Green Fluorescent Protein (GFP) under the control of a human 630 Phosphoglycerate Kinase promoter (PGK) (Cesana et al., 2014) and a pCMV expressing vector 631 containing the SARS-CoV-2 Spike sequence (accession number MN908947) that was codonoptimized for human expression and contained a deletion at the 3' end aimed at deleting 19 amino acid residues at the C-terminus. An HIV gag-pol packaging construct and a revencoding plasmid were co-transfected by calcium phosphate for the production of infective viral particles. $16 \mathrm{~h}$ after transfection, the medium was replaced and $30 \mathrm{~h}$ later, supernatant was 636 collected, filtered through $0.22 \mu \mathrm{m}$ pore nitrocellulose filter and viral particles were pelleted 637 by ultracentrifugation. As control, lentivirus particles were pseudotyped with the VSV-g glycoprotein that allows a high efficiency infection independently of binding to ACE2.

\section{Pseudotyped lentivirus binding assay}

96-well Nunc Maxisorp Immunoplates (Costar, USA) were coated with $100 \mu \mathrm{L}$ of rhMBL (3 and $1 \mu \mathrm{g} / \mathrm{mL}-10$ and $3.4 \mathrm{nM}$ diluted in PBS). After overnight incubation, plates

642 were blocked with $2 \%$ BSA diluted in $\mathrm{TBST}^{-\mathrm{Ca}^{2+}}$ for $1 \mathrm{~h}$ at $37^{\circ} \mathrm{C}$, washed three times with 643 TBST-Ca ${ }^{2+}$ and incubated for $1 \mathrm{~h}$ with $100 \mu \mathrm{L}$ of SARS-CoV-2 Spike protein-pseudotyped 644 lentivirus or VSV-pseudotyped lentivirus (ranging fom 0.1 to $1 \mu \mathrm{g} / \mathrm{mL}$ diluted in TBST- $\mathrm{Ca}^{2+}$ ). 645 After washing, bound pseudotyped virus particles were lysed with 0.5\% Triton X-100 and HIV 646 p24 core protein was detected by ELISA (Perkin Elmer; USA). 
medRxiv preprint doi: https://doi.org/10.1101/2021.06.07.21258350; this version posted June 8, 2021. The copyright holder for this preprint (which was not certified by peer review) is the author/funder, who has granted medRxiv a license to display the preprint in perpetuity. All rights reserved. No reuse allowed without permission.

647

648

649

650

651

652

653

654

655

656

657

658

659

660

661

662

663

664

665

666

667

668

669

670

\section{Complement deposition assay}

$100 \mu \mathrm{L}$ of biotinylated SARS-CoV-2 Spike protein (either active trimer or non-covalent trimer, $1 \mu \mathrm{g} / \mathrm{mL}$ in PBS) were captured on 96 well plates for $1 \mathrm{~h}$ at $37^{\circ} \mathrm{C}$. After washing, wells were incubated for $1 \mathrm{~h}$ at $37^{\circ} \mathrm{C}$ with either $10 \%$ normal human serum (NHS, ComplemenTech Inc, USA), 10\% C1q-depleted serum (C1qDHS), 10\% C4-depleted serum (C4DHS) reconstituted or not with $25 \mu \mathrm{g} / \mathrm{mL}$ purified C4 (Calbiochem, USA). 10\% heat-inactivated human serum (30' at $56^{\circ} \mathrm{C}$, HI-NHS) and 10\% C3-depleted serum (C3DHS) were used as negative control. All the sera were diluted in $10 \mathrm{mM}$ Tris-buffered saline containing $0.5 \mathrm{mM}$ $\mathrm{MgCl}_{2}, 2 \mathrm{mM} \mathrm{CaCl}$ and $0.05 \%$ Tween-20, also used as washing buffer. For MBL immunodepletion, $10 \%$ NHS was incubated overnight with $0.6 \mu \mathrm{g} / \mathrm{mL}$ rabbit anti-MBL antibody. Bound MBL-antibody complexes were separated by Dynabeads Protein G (Thermo Fisher Scientific), and the supernatant (termed MBL-ID) was used in the assay (final concentration, 10\%). After washing, C5b-9 deposition was assayed by incubation for $1 \mathrm{~h}$ at $37^{\circ} \mathrm{C}$ with rabbit anti-sC5b-9 antibody (ComplemenTech Inc., Usa) diluted 1:2000 in washing buffer as described before (Stravalaci et al., 2020), followed by specific HRP-conjugated secondary antibody incubation and TMB development.

\section{Cell Lines}

The Vero and Vero E6 cell line was obtained from the Istituto Zooprofilattico of Brescia, Italy, and ATCC, respectively. Cells were maintained in Eagle's minimum essential medium (EMEM; Lonza) supplemented with 10\% fetal bovine serum (FBS; Euroclone) and penicillin-streptomycin (complete medium).

Human embryonic kidney $293 \mathrm{~T}$ cells, a continuous human embryonic kidney cell line containing the mutant gene of SV40 Large T Antigen (ATCC code CRL-3216), were cultured as described (Follenzi et al., 2000). 
medRxiv preprint doi: https://doi.org/10.1101/2021.06.07.21258350; this version posted June 8, 2021. The copyright holder for this preprint (which was not certified by peer review) is the author/funder, who has granted medRxiv a license to display the preprint in perpetuity. All rights reserved. No reuse allowed without permission.

672 grown in EMEM supplemented with 20\% FBS and penicillin-streptomycin (complete

673 medium).

674 Human Bronchial Epithelial Cells (HBEC)

The isolation, culture, and differentiation of primary human bronchial epithelial cells

676 (HBECs) were performed as previously reported (Scudieri et al., 2012), with some

677 modifications. In brief, epithelial cells were obtained from mainstem human bronchi, derived

678 from individuals undergoing lung transplant. For the present study, cells were obtained from

679 three donors (BE37, BE63 and BE177). Epithelial cells were detached by overnight treatment

680 of bronchi with protease XIV and then were cultured in a serum-free medium (LHC9 mixed

681

with RPMI 1640, 1:1) containing supplements, as described (Scudieri et al., 2012). The

682

collection of bronchial epithelial cells and their study to investigate airway epithelium

683

physiopathology were specifically approved by the Ethics Committee of the Istituto Giannina

684 Gaslini following the guidelines of the Italian Ministry of Health (registration number:

685 ANTECER, 042-09/07/2018). Each patient provided informed consent to the study using a

686 form that was also approved by the Ethics Committee.

687

To obtain differentiated epithelia, cells were seeded at high density $\left(5 \times 10^{5}\right.$

688

cell/snapwell) on 12-mm diameter porous membranes (Snapwell inserts, Corning, code 3801).

689 After 24 hours, the serum-free medium was removed from both sides and, on the basolateral

690 side only, replaced with Pneumacult ALI medium (StemCell Technologies) and differentiation

691 of cells (for 3 weeks) was performed in air-liquid interface (ALI) condition.

Entry assay with SARS-CoV-2 Spike- pseudotyped lentivirus particles

$293 \mathrm{~T}$ cells were engineered to overexpress the SARS-CoV-2 entry receptor by

694 transduction of a lentiviral vector expressing ACE2 (kindly provided by Massimo Pizzato,

695 University of Trento). Lentiviral vector stock expressing ACE2 was produced as described 
medRxiv preprint doi: https://doi.org/10.1101/2021.06.07.21258350; this version posted June 8, 2021. The copyright holder for this preprint (which was not certified by peer review) is the author/funder, who has granted medRxiv a license to display the preprint in perpetuity.

696

697

698

699

700

701

702

703

704

705

706

707

708

709

710

711

712

713

714

715

716

718

719

720

above. The entry assay was then optimized in 96 -well plate by seeding $5 \times 10^{4}$ ACE2 overexpressing $293 \mathrm{~T}$ cells/well. Twenty-four $\mathrm{h}$ later, cells and SARS-CoV-2 Spikepseudotyped lentivirus stock (1:500) were incubated with serial dilutions of soluble innate immunity molecules for $30 \mathrm{~min}$. The SARS-CoV-2 Spike-pseudotyped was added to the cells and forty-eight $\mathrm{h}$ later, cells were treated with accutase, in order to detach them from the wells, fixed and analyzed for GFP expression by cytofluorimetry.

\section{SARS-CoV-2 viral isolates}

The SARS-CoV-2 isolate of the B.1 lineage with the Spike D614G mutation (GISAID accession ID: EPI_ISL_413489) was obtained from the nasopharyngeal swab of a mildly symptomatic patient by inoculation of Vero E6 cells as described (Clementi et al., 2020; Mycroft-West et al., 2020). The SARS-CoV-2 isolate of the South African B1.351 lineage (GISAID accession ID: EPI_ISL_1599180) was obtained from the nasopharyngeal swab of an Italian 80-year-old male patient. The SARS-CoV-2 isolate of the B1.1.7 lineage (GISAID accession ID: EPI_ISL_1924880) was obtained from the nasopharyngeal swab of an Italian 58-year-old female patient. Secondary viral stocks were generated by infection of adherent Vero E6 cells seeded in a $25 \mathrm{~cm}^{2}$ tissue culture flask with $0.5 \mathrm{ml}$ of the primary isolate diluted in $5 \mathrm{ml}$ of complete medium. Three days after infection, the supernatant was harvested and, after centrifugation, passed through a $0.45 \mu \mathrm{m}$ filter. Aliquots of the secondary SARS-CoV-2 isolate were maintained at $-80{ }^{\circ} \mathrm{C}$. A plaque-forming assay was performed to determine viral titers.

\section{Infections}

Calu-3 cells were seeded in 48 -well plates (Corning) at the concentration of $5 \times 10^{4}$ cell/well in complete medium $24 \mathrm{~h}$ prior to infection. Ten-fold serial dilutions of MBL (from 0.01 to $10 \mu \mathrm{g} / \mathrm{ml}-0.034-34 \mathrm{nM}$ ) were incubated for $1 \mathrm{~h}$ with aliquots of SARS-CoV-2 containing supernatant to obtain a multiplicity of infection (MOI) of either 0.1 or 1 before 
medRxiv preprint doi: https://doi.org/10.1101/2021.06.07.21258350; this version posted June 8, 2021. The copyright holder for this preprint (which was not certified by peer review) is the author/funder, who has granted medRxiv a license to display the preprint in perpetuity.

incubation with Calu-3 cells (Virus+MBL). After 48 and $72 \mathrm{~h}$ post-infection (PI), cell culture supernatants were collected and stored at $-80^{\circ} \mathrm{C}$ until determination of the viral titers by a plaque-forming assay in Vero cells.

Virus incubation with MBL was also combined with incubation of target cells. Briefly, virus incubation with MBL was performed as described above whereas Calu-3 cells were incubated with 10-fold serial dilutions of MBL (from 0.01 to $10 \mu \mathrm{g} / \mathrm{ml}-0.034-34 \mathrm{nM}$ ). After $1 \mathrm{~h}$, virus suspensions incubated with serial dilutions of MBL were added to MBL-treated cells (Virus+ Cells+MBL). After 48 and 72 h POST, cell culture supernatants were collected and stored at $-80{ }^{\circ} \mathrm{C}$ until determination of the viral titers by a plaque-forming assay in Vero cells. Forty-eight $\mathrm{h}$ before infection, the apical surface of HBEC was washed with $500 \mu \mathrm{l}$ of PBS for 1.5 hours at $37^{\circ} \mathrm{C}$, and the cultures were moved into fresh air liquid interface media. Immediately before infection, apical surfaces were washed twice to remove accumulated mucus with $500 \mu \mathrm{l}$ of PBS with each wash lasting $30 \mathrm{~min}$ at $37^{\circ} \mathrm{C}$. Two concentrations of either PTX3 or MBL were added to the apical surface for $1 \mathrm{~h}$ prior to the addition of $100 \mu \mathrm{l}$ of viral inoculum (SARS-CoV-2) at a MOI of 1 . HBEC were incubated for $2 \mathrm{~h}$ at $37^{\circ} \mathrm{C}$. Viral inoculum was then removed and the apical surface of the cultures was washed three times with $500 \mu$ of PBS. Cultures were incubated at $37^{\circ} \mathrm{C}$ for $72 \mathrm{~h}$ PI. Infectious virus produced by the $\mathrm{HBEC}$ was collected by washing the apical surface of the culture with $100 \mu \mathrm{l}$ of PBS every $24 \mathrm{~h}$ up to 72 h PI. Apical washes were stored at $-80^{\circ} \mathrm{C}$ until analysis and titered by plaque assay in Vero cells. At 72 h PI, cells were fixed in 4\% paraformaldehyde for immunofluorescence analysis. All infection experiments were performed in a biosafety level 3 (BSL-3) laboratory at the Laboratory of Medical Microbiology and Virology, Vita-Salute San Raffaele University.

\section{Chemokine quantification}

Half of the ALI medium $(1 \mathrm{ml})$ was collected from each well of the lower chamber every $24 \mathrm{~h}$ PI and replaced with fresh ALI medium. The harvested medium was stored at -70 
medRxiv preprint doi: https://doi.org/10.1101/2021.06.07.21258350; this version posted June 8, 2021. The copyright holder for this preprint (which was not certified by peer review) is the author/funder, who has granted medRxiv a license to display the preprint in perpetuity. All rights reserved. No reuse allowed without permission.

${ }^{\circ} \mathrm{C}$ until analysis. Prior to chemokine quantification, $250 \mu 1$ of medium was treated with $27 \mu 1$ of Triton X-100 and heated for $30 \mathrm{~min}$ at $56^{\circ} \mathrm{C}$ to inactivate SARS-CoV-2 infectivity.

Chemokines (IL-8 and CXCL5) were quantified by ELISA (Quantikine ELISA kits, code DY208, DY254, R\&D Systems).

\section{Plaque-forming assay}

In order to measure the virus titer of the viral stocks, a plaque-forming assay was optimized in Vero cells. Briefly, confluent Vero cells $\left(1.5 \times 10^{6}\right.$ cell/well) seeded in 6 -well plates (Corning) were incubated in duplicate with $1 \mathrm{ml}$ of EMEM supplemented with $1 \% \mathrm{FBS}$ containing 10-fold serial dilutions of SARS-CoV-2 stock. After $1 \mathrm{~h}$ of incubation, the viral inoculum was removed and methylcellulose (Sigma; $1 \mathrm{ml}$ in EMEM supplemented with 5\% FBS) was overlaid on each well. After 4 days of incubation, the cells were stained with $1 \%$ crystal violet (Sigma) in $70 \%$ methanol. The plaques were counted after examination with a stereoscopic microscope (SMZ-1500; Nikon Instruments) and the virus titer was calculated in terms of plaque forming units (PFU)/ml.

In order to determine the viral titers of the supernatant collected from Calu-3 cells at 48 and $72 \mathrm{~h}$ PI, confluent Vero cells $\left(2.5 \times 10^{5}\right.$ cell/well) were seeded in 24 -well plates (Corning) $24 \mathrm{~h}$ prior to infection. Then, cells were incubated with $300 \mu \mathrm{l}$ of EMEM supplemented with 1\% FBS containing serially diluted (1:10) virus-containing supernatants. The plaque-forming assay was performed as described above.

\section{Confocal and STED super-resolution microscopy}

After 4\% PFA fixation, HBEC cultures were incubated for $1 \mathrm{~h}$ with PBS and $0.1 \%$ Triton X-100 (Sigma-Aldrich), 5\% normal donkey serum (Sigma-Aldrich), 2\% BSA, 0.05\% Tween (blocking buffer). Cells were then incubated for $2 \mathrm{~h}$ in blocking buffer with the following primary antibodies: mouse anti-cytokeratin $14(\mathrm{Krt14})\left(\# \mathrm{LL} 002 ; 1 \mu \mathrm{g} / \mathrm{ml}\right.$; cat. $\mathrm{N}^{\circ} 33$ 168, ProSci-Incorporated, US); rabbit polyclonal anti-Spike protein (944-1218aa) $(2 \mu \mathrm{g} / \mathrm{ml}$; cat. 
medRxiv preprint doi: https://doi.org/10.1101/2021.06.07.21258350; this version posted June 8, 2021. The copyright holder for this preprint (which was not certified by peer review) is the author/funder, who has granted medRxiv a license to display the preprint in perpetuity. All rights reserved. No reuse allowed without permission.

771

$\mathrm{N}^{\circ}$ 28867-1-AP, Proteintech ${ }^{\circledR}$, Germany); rat anti-MBL (\#8G6; $1 \mu \mathrm{g} / \mathrm{ml}$; cat. $\mathrm{N}^{\circ} \mathrm{HM} 1035$, Hycult ${ }^{\circledR}$ Biotech) and rat anti-MBL (\#14D12; $1 \mu \mathrm{g} / \mathrm{ml}$; cat. $\mathrm{N}^{\circ} \mathrm{HM} 1038$, Hycult ${ }^{\circledR}$ Biotech). After washing with PBS and $0.05 \%$ Tween, cells were incubated for $1 \mathrm{~h}$ with the following speciesspecific cross-adsorbed secondary antibodies form Invitrogen-ThermoFisher Scientific: donkey anti-rabbit IgG Alexa Fluor ${ }^{\circledR} 488\left(1 \mu \mathrm{g} / \mathrm{ml}\right.$; cat. $\mathrm{N}^{\circ}$ A-21206); donkey anti-rat IgG Alexa Fluor ${ }^{\circledR} 594\left(1 \mu \mathrm{g} / \mathrm{ml}\right.$; cat. $\mathrm{N}^{\circ}$ A-21209); donkey anti-mouse IgG Alexa Fluor ${ }^{\circledR} 647$ (1 $\mu \mathrm{g} / \mathrm{ml}$; cat. $\left.\mathrm{N}^{\circ} \mathrm{A}-31571\right) .4$,'6-diamidino-2-phenylindole (DAPI) (Invitrogen) was used for nucleus staining. Cells were mounted with Mowiol $^{\circledR}$ (Sigma-Aldrich) and analyzed with a Leica SP8 STED3X confocal microscope system equipped with a Leica HC PLAPO CS2 63X/1.40 oil immersion lens. Confocal images (1.024 X 1.024 pixels) were acquired in $X Y Z$ and tiling modality $(0.25 \mu \mathrm{m}$ slice thickness) and at 1 Airy Unit (AU) of lateral resolution (pinhole aperture of $95.5 \mu \mathrm{m}$ ) at a frequency of $600 \mathrm{~Hz}$ in bidirectional mode. Alexa Fluor $488^{\circledR}$ was excited with a $488 \mathrm{~nm}$ argon laser and emission collected from 505 to 550nm. Alexa Fluor $594{ }^{\circledR}$ was excited with a 594/604nm-tuned white light laser and emission collected from 580 to $620 \mathrm{~nm}$. Alexa Fluor $5647^{\circledR}$ was excited with a $640 / 648 \mathrm{~nm}$-tuned white light laser and emission collected from 670 to $750 \mathrm{~nm}$. Frame sequential acquisition was applied to avoid fluorescence overlap. A gating between 0.4 and $7 \mathrm{~ns}$ was applied to avoid collection of reflection and autofluorescence. 3D STED analysis was performed using the same acquisition set-up. A $660 \mathrm{~nm} \mathrm{CW}$-depletion laser (30\% of power) was used for excitations of Alexa Fluor $488^{\circledR}$ (Spike signal) and Alexa Fluor $5944^{\circledR}$ (MBL signal). STED images were acquired with a Leica HC PL APO 100×/1.40 oil STED White objective at 572.3 milli absorption unit (mAU). CW-STED and gated CW-STED were applied to Alexa Fluor $488^{\circledR}$ and Alexa Fluor $594^{\circledR}$, respectively. Confocal images were processed, 3D rendered and analyzed as colocalization rate between Spike and MBL with Leica Application Suite X software (LASX; version 3.5.5.19976) and presented as medium intensity projection (MIP). STED images were de- 
medRxiv preprint doi: https://doi.org/10.1101/2021.06.07.21258350; this version posted June 8, 2021. The copyright holder for this preprint (which was not certified by peer review) is the author/funder, who has granted medRxiv a license to display the preprint in perpetuity. All rights reserved. No reuse allowed without permission.

convolved with Huygens Professional software (Scientific Volume Imaging B. V.; version 19.10) and presented as MIP.

\section{Patient cohorts for genetic analyses}

For association analyses, we investigated a total of 2,000 individuals. These included:

i) 332 patients with severe COVID-19, which was defined as hospitalization with respiratory failure and a confirmed SARS-CoV-2 viral RNA PCR test from nasopharyngeal swabs. Patients were recruited from intensive care units and general wards at two hospitals in the Milan area, i.e., the Humanitas Clinical and Research Center, IRCCS, in Rozzano, Italy (140 patients); and San Gerardo Hospital, in Monza, Italy (192 patients); ii) 1,668 controls from the general Italian population with unknown COVID-19 status.

Details on DNA extraction, array genotyping and quality checks are reported elsewhere (Myocardial Infarction Genetics et al., 2009; Severe Covid et al., 2020). The dataset for cases was submitted to the European Bioinformatics Institute (www.ebi.ac.uk/gwas) under accession numbers GCST90000255 and GCST90000256, whereas the dataset for controls is deposited in the Genotypes and Phenotypes database (dbGaP; https://www.ncbi.nlm.nih.gov/gap/), under the phs000294.v1.p1 accession code.

Approvals for the project were obtained from the relevant ethics committees (Humanitas Clinical and Research Center, reference number, 316/20; the University of MilanoBicocca School of Medicine, San Gerardo Hospital, reference number, 84/2020).

\section{Imputation}

Genetic coverage was increased by performing single-nucleotide polymorphism (SNP) imputation on the genome build GRCh38 using the Michigan Imputation Server (https://imputation.biodatacatalyst.nhlbi.nih.gov/index.html\#!) and haplotypes generated by the Trans-Omics for Precision Medicine (TOPMed) program (freeze 5) (Taliun et al., 2021), for both cases and controls. In the imputation, we used the population panel "ALL" and applied 
medRxiv preprint doi: https://doi.org/10.1101/2021.06.07.21258350; this version posted June 8, 2021. The copyright holder for this preprint (which was not certified by peer review) is the author/funder, who has granted medRxiv a license to display the preprint in perpetuity. All rights reserved. No reuse allowed without permission.

821

the server options to filter by an imputation of $\mathrm{R}^{2}>0.1$. In the post-imputation steps, we only retained those SNPs with $\mathrm{R}^{2} \geq 0.6$ and minor allele frequency (MAF) $\geq 1 \%$. Next, we accurately checked cases and controls for solving within-Italian relationships and for testing the possible existence of population stratification within and across batches: to this aim, we performed principal component analysis (PCA), using a LD-pruned subset of SNPs across chromosome 10 and the Plink v.1.9 package (Chang et al., 2015). The final set of analyzed variants comprised 3,425 SNPs, distributed in the MBL2 region (the gene $+/-500 \mathrm{~kb}$ ).

\section{Statistical analysis}

Prism GraphPad software v. 8.0 (www.graphpad.com) was used for the statistical analyses. Comparison among groups were performed using one or two-way analysis of variance (ANOVA) and the Bonferroni's correction. Non-linear fit of transformed data was determined by using the log (agonist) vs. response (three or four parameters).

For genetic studies, case-control allele-dose association tests were performed using the PLINK v.1.9 logistic-regression framework for dosage data. Age, sex, age*age, sex*age, and the first 10 principal components from PCA were introduced in the model as covariates. Analyses were conducted always referring to the minor allele. All $\mathrm{P}$ values are presented as not corrected and accompanied by odds ratio (OR) and $95 \%$ confidence interval (CI); however, in the relevant table/figure, Bonferroni-corrected thresholds for significance are indicated in the footnote/legend.

Haplotype analysis was performed in two ways: i) by selecting relevant SNPs and using the -hap-logistic option implemented in PLINK v.1.07 (Purcell et al., 2007); ii) by an unsupervised approach by means of the Beagle software v3.3 (http://faculty.washington.edu/browning/beagle/b3.html), which uses the method described by Browning \& Browning (Browning and Browning, 2007) for inferring haplotype phase. In this case, we used the default setting of 1,000 permutations for calculating corrected $\mathrm{P}$ values. 
medRxiv preprint doi: https://doi.org/10.1101/2021.06.07.21258350; this version posted June 8, 2021. The copyright holder for this preprint (which was not certified by peer review) is the author/funder, who has granted medRxiv a license to display the preprint in perpetuity. All rights reserved. No reuse allowed without permission.

847 - Genetic Center database (https://rgc-covid19.regeneron.com/home) for the GHS study

848 (Geisinger Health System; data available for 869 cases and 112,862 controls of European

849 ancestry). Pooled Ors and Cis were calculated using the Mantel-Haenszel model (Mantel and

$850 \quad$ Haenszel, 1959)

851 
medRxiv preprint doi: https://doi.org/10.1101/2021.06.07.21258350; this version posted June 8, 2021. The copyright holder for this preprint (which was not certified by peer review) is the author/funder, who has granted medRxiv a license to display the preprint in perpetuity.

854 Supplementary Table 1. Recombinant SARS-CoV-2 proteins used in this study.

\begin{tabular}{|c|c|c|c|}
\hline Proteins & Host & Cat & Company \\
\hline SARS-CoV-2 S1 protein, His Tag & HEK293 & $\mathrm{S} 1 \mathrm{~N}-\mathrm{C} 52 \mathrm{H} 4$ & ACROBiosystems \\
\hline SARS-CoV-2 S2 protein, His Tag & HEK293 & S2N-C52H5 & ACROBiosystems \\
\hline SARS-CoV-2 S protein, His Tag, active trimer & HEK293 & SPN-C52H8 & ACROBiosystems \\
\hline SARS-CoV-2 Nucleocapsid protein, His Tag & HEK293 & NUN-C5227 & ACROBiosystems \\
\hline SARS-CoV-2 Envelope protein. GST, His Tag & E.coli & ENN-C5128 & ACROBiosystems \\
\hline $\begin{array}{l}\text { Biotinylated SARS-CoV-2 S protein, His Tag, active } \\
\text { trimer }\end{array}$ & HEK293 & SPN-C82E3 & ACROBiosystems \\
\hline Biotinlyated SARS-CoV-2 Nucleocapsid protein, His Tag & HEK293 & NUN-C82E8 & ACROBiosystems \\
\hline SARS-CoV-2 S protein, His Tag & HEK293 & 10549-CV & R\&D Systems \\
\hline SARS-CoV-2 Nucleocapsid protein, His Tag & HEK293 & $230-30164$ & RayBiotech \\
\hline SARS-CoV-2 $\mathrm{S}$ protein, His Tag & HEK293 & In house & $\begin{array}{l}\text { (Andreano et al., } \\
2020)\end{array}$ \\
\hline SARS-CoV-2 S protein trimer, His Tag & $\begin{array}{l}\text { EXPI293F } \\
\text { cells }\end{array}$ & In house & $\begin{array}{l}\text { (De Gasparo et al., } \\
\text { 2021) }\end{array}$ \\
\hline SARS-CoV-2 $\mathrm{S}$ protein, His Tag & $\mathrm{CHO}$ & $\begin{array}{l}\text { XLGCOV-1- } \\
\text { PPTH }\end{array}$ & ExcellGene \\
\hline SARS-CoV-2 (2019-nCoV) Spike RBD, His Tag & HEK293 & 40592-V08H & Sino Biological \\
\hline SARS-CoV-2 (2019-nCoV) Spike S1+S2 ECD, His Tag & $\begin{array}{l}\text { Insect } \\
\text { cells }\end{array}$ & 40589-V08B1 & Sino Biological \\
\hline $\begin{array}{l}\text { SARS-CoV-2 (2019-nCoV) Spike S1+S2 ECD (B.1.1.7), } \\
\text { His Tag }\end{array}$ & $\begin{array}{l}\text { Insect } \\
\text { cells }\end{array}$ & 40589-V08B6 & Sino Biological \\
\hline SARS-CoV-2 S protein (D614G), His Tag & HEK293 & SPN-C52H3 & ACROBiosystems \\
\hline SARS-CoV-2 S protein (B.1.1.7 variant), His Tag & HEK293 & SPN-C52H6 & ACROBiosystems \\
\hline SARS-CoV-2 S protein (B.1.351 variant), His Tag & HEK293 & SPN-C52Hc & ACROBiosystems \\
\hline SARS-CoV-2 S protein (B.1.1.28 variant), His Tag & HEK293 & SPN-C52Hg & ACROBiosystems \\
\hline
\end{tabular}


medRxiv preprint doi: https://doi.org/10.1101/2021.06.07.21258350; this version posted June 8, 2021. The copyright holder for this preprint (which was not certified by peer review) is the author/funder, who has granted medRxiv a license to display the preprint in perpetuity. All rights reserved. No reuse allowed without permission.

\section{Supplementary Figures}

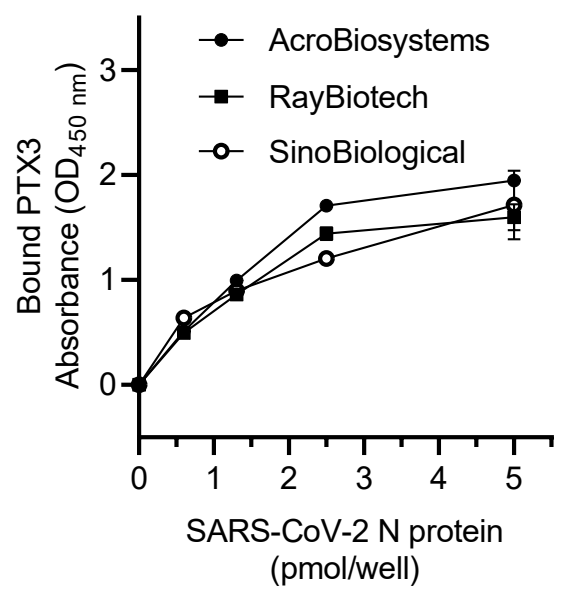

859

861 proteins from different companies. Data are presented as mean \pm SEM of one experiment 862 performed in duplicate. 
medRxiv preprint doi: https://doi.org/10.1101/2021.06.07.21258350; this version posted June 8, 2021. The copyright holder for this preprint (which was not certified by peer review) is the author/funder, who has granted medRxiv a license to display the preprint in perpetuity. All rights reserved. No reuse allowed without permission.

864
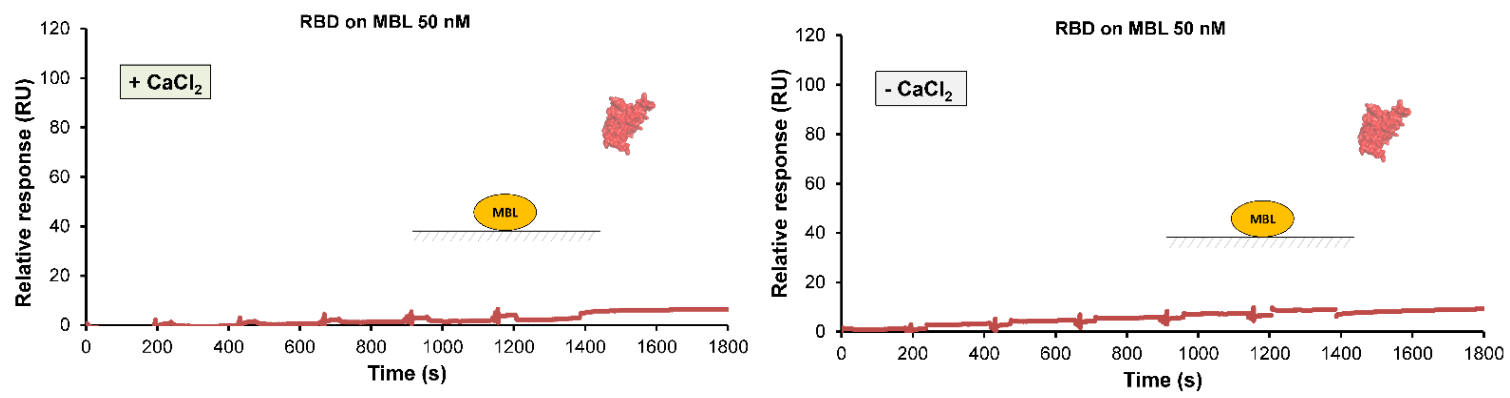

865

866 Supplementary Figure 2. Interaction between recombinant RBD and immobilized MBL in

867 the presence or absence of calcium, as assessed by SPR analysis.

868 
medRxiv preprint doi: https://doi.org/10.1101/2021.06.07.21258350; this version posted June 8,2021 . The copyright holder for this preprint (which was not certified by peer review) is the author/funder, who has granted medRxiv a license to display the preprint in perpetuity.

A
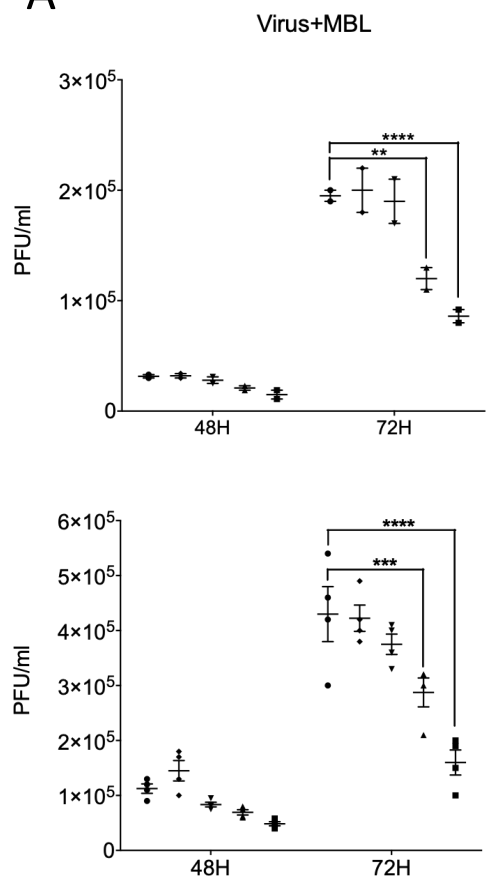

C

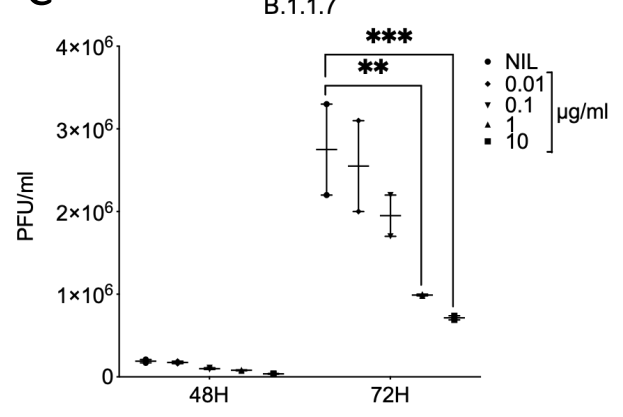

B

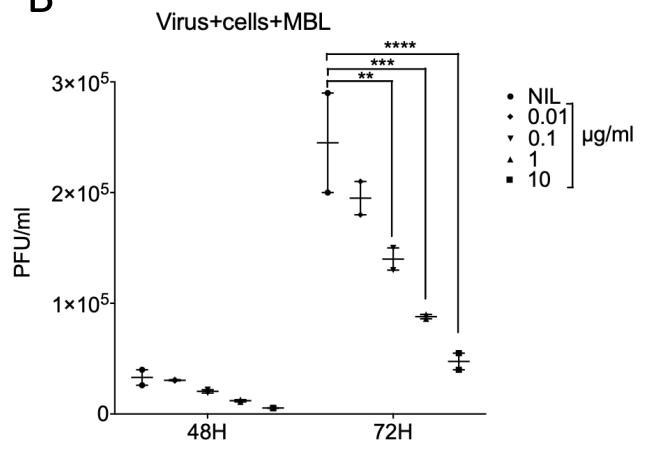

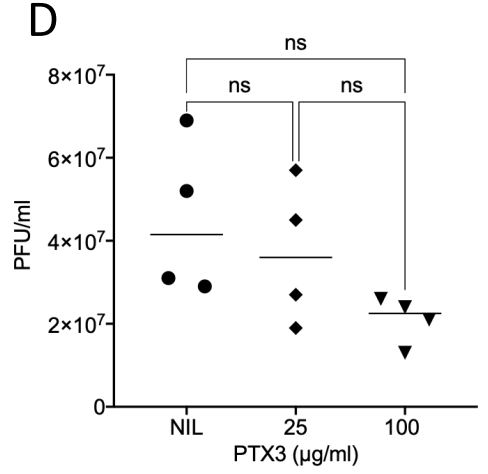
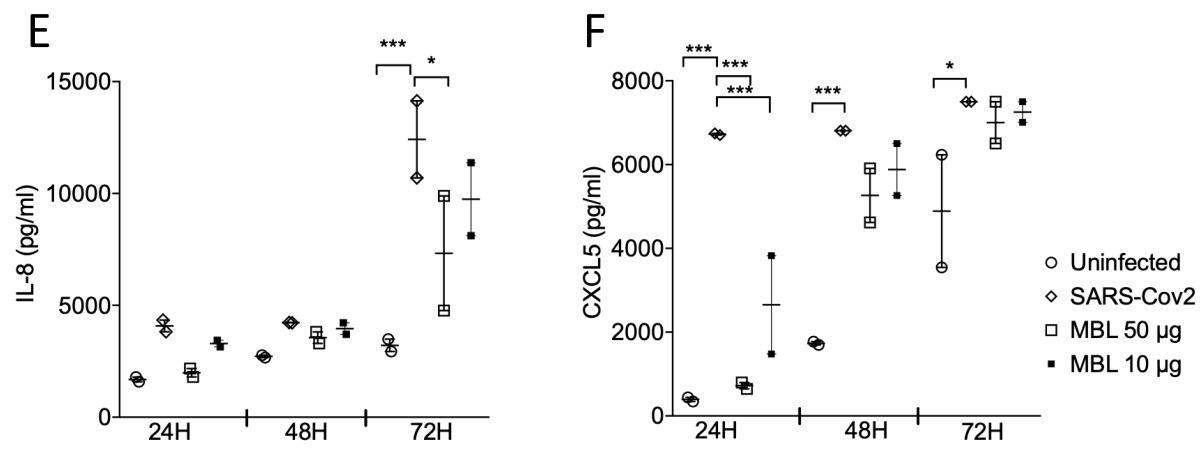

871 Supplementary Figure 3. Inhibition of viral infection and chemokine production by MBL.

872 (A-C) Inhibition of the infectivity of the D614G (isolate EPI_ISL_413489) (A, B) and B.1.1.7

873 (C) SARS-CoV-2 variants by MBL in Calu-3 cells. SARS-CoV-2 (A upper panel, B and C, 
medRxiv preprint doi: https://doi.org/10.1101/2021.06.07.21258350; this version posted June 8,2021 . The copyright holder for this preprint (which was not certified by peer review) is the author/funder, who has granted medRxiv a license to display the preprint in perpetuity. All rights reserved. No reuse allowed without permission.

$874 \mathrm{MOI}=0.1$; A lower panels, $\mathrm{MOI}=1$ ) was preincubated in complete medium containing different 875 concentrations of MBL $(0.01-10 \mu \mathrm{g} / \mathrm{mL}-0.034-34 \mathrm{nM})$ before incubation with Calu-3 cells

876 (Virus + MBL) (A), or both virus and cells were pre-incubated with the same concentrations

877 of MBL (Virus + Cells + MBL) (B, C). After 48 and $72 \mathrm{~h}$, the infectivity of SARS-CoV-2 present

878 in cell culture supernatants was determined by a plaque-forming assay in Vero cells. NIL: no

879 MBL. (D) SARS-CoV-2 production at the HBEC apical surface at $72 \mathrm{~h}$ PI, in the presence of

88025 or $100 \mu \mathrm{g} / \mathrm{ml}$ (75 or $300 \mathrm{nM}$ ) PTX3. (E) Chemokine production by SARS-CoV-2 infected

881 HBEC in the presence of MBL. Mean values of two $(A, B, D)$ or one $(C, E)$ experiments in

882 duplicate cell culture are shown. ${ }^{* * * *}$ p value $<0.0001, * * *$ p value $<0.001,{ }^{* *}$ p value $<0.01$ as

883 determined by two-way (A, B, C, E) or one-way (D) ANOVA with Bonferroni's correction.

884

885

886

Movie S1. SARS-CoV-2 S protein and MBL colocalized on infected HBEC cells. 3D

887 rendering showing a blended reconstruction of the colocalization between SARS-CoV-2 S

888 protein and MBL in HBEC cultures, preferentially associated to the apical side. 
medRxiv preprint doi: https://doi.org/10.1101/2021.06.07.21258350; this version posted June 8, 2021. The copyright holder for this preprint (which was not certified by peer review) is the author/funder, who has granted medRxiv a license to display the preprint in perpetuity.

890

891

892

893

894

895

896

897

898

899

900

901

902

903

904

905

906

907

908

909

910

911

912

913

914

915

916

917

918

919

920

\section{References}

Andreano, E., Piccini, G., Licastro, D., Casalino, L., Johnson, N.V., Paciello, I., Monego, S.D., Pantano, E., Manganaro, N., Manenti, A., et al. (2020). SARS-CoV-2 escape in vitro from a highly neutralizing COVID-19 convalescent plasma. bioRxiv. doi.org/10.1101/2020.12.28.424451.

Berisio, R., Vitagliano, L., Mazzarella, L., and Zagari, A. (2002). Crystal structure of the collagen triple helix model [(Pro-Pro-Gly)(10)](3). Protein Sci 11, 262-270.

Bottazzi, B., Doni, A., Garlanda, C., and Mantovani, A. (2010). An integrated view of humoral innate immunity: pentraxins as a paradigm. Annu Rev Immunol 28, 157-183.

Bottazzi, B., Vouret-Craviari, V., Bastone, A., De Gioia, L., Matteucci, C., Peri, G., Spreafico, F., Pausa, M., D'Ettorre, C., Gianazza, E., et al. (1997). Multimer formation and ligand recognition by the long pentraxin PTX3. Similarities and differences with the short pentraxins C-reactive protein and serum amyloid P component. J Biol Chem 272, 3281732823.

Bozza, S., Bistoni, F., Gaziano, R., Pitzurra, L., Zelante, T., Bonifazi, P., Perruccio, K., Bellocchio, S., Neri, M., Iorio, A.M., et al. (2006). Pentraxin 3 protects from MCMV infection and reactivation through TLR sensing pathways leading to IRF3 activation. Blood 108, 3387-3396.

Browning, S.R., and Browning, B.L. (2007). Rapid and accurate haplotype phasing and missing-data inference for whole-genome association studies by use of localized haplotype clustering. Am J Hum Genet 81, 1084-1097.

Brunetta, E., Folci, M., Bottazzi, B., De Santis, M., Gritti, G., Protti, A., Mapelli, S.N., Bonovas, S., Piovani, D., Leone, R., et al. (2021). Macrophage expression and prognostic significance of the long pentraxin PTX3 in COVID-19. Nat Immunol 22, 19-24.

Carvelli, J., Demaria, O., Vely, F., Batista, L., Chouaki Benmansour, N., Fares, J., Carpentier, S., Thibult, M.L., Morel, A., Remark, R., et al. (2020). Association of COVID-19 inflammation with activation of the C5a-C5aR1 axis. Nature 588, 146-150.

Casalino, L., Gaieb, Z., Goldsmith, J.A., Hjorth, C.K., Dommer, A.C., Harbison, A.M., Fogarty, C.A., Barros, E.P., Taylor, B.C., McLellan, J.S., et al. (2020). Beyond Shielding: The Roles of Glycans in the SARS-CoV-2 Spike Protein. ACS Cent Sci 6, 17221734. 
medRxiv preprint doi: https://doi.org/10.1101/2021.06.07.21258350; this version posted June 8, 2021. The copyright holder for this preprint (which was not certified by peer review) is the author/funder, who has granted medRxiv a license to display the preprint in perpetuity. S., Benedicenti, F., Sergi Sergi, L., Sanvito, F., et al. (2014). Uncovering and dissecting the genotoxicity of self-inactivating lentiviral vectors in vivo. Mol Ther 22, 774-785. (2015). Second-generation PLINK: rising to the challenge of larger and richer datasets.

926 Gigascience 4, 7. Lorenzo, F., Garcia-Rivera, D., Valdes-Balbin, Y., Verez-Bencomo, V., et al. (2020). Novel ACE2-Independent Carbohydrate-Binding of SARS-CoV-2 Spike Protein to Host Lectins and Lung Microbiota. bioRxiv, doi.org/10.1101/2020.05.13.092478.

932 Tsang, J.O., Huang, X., et al. (2020). Comparative tropism, replication kinetics, and cell

933 damage profiling of SARS-CoV-2 and SARS-CoV with implications for clinical manifestations, transmissibility, and laboratory studies of COVID-19: an observational study. Lancet Microbe 1, e14-e23.

937 Burioni, R., Clementi, M., and Mancini, N. (2020). Combined Prophylactic and Therapeutic 938 Use Maximizes Hydroxychloroquine Anti-SARS-CoV-2 Effects in vitro. Front Microbiol 11, 9391704.

Consortium, T.U. (2020). UniProt: the universal protein knowledgebase in 2021. Nucleic Acids Res 49, D480-D489.

De Gasparo, R., Pedotti, M., Simonelli, L., Nickl, P., Muecksch, F., Cassaniti, I.,

943 Percivalle, E., Lorenzi, J.C.C., Mazzola, F., Magri, D., et al. (2021). Bispecific IgG

944 neutralizes SARS-CoV-2 variants and prevents escape in mice. Nature 593, 424-428.

945 Desmyter, J., Melnick, J.L., and Rawls, W.E. (1968). Defectiveness of interferon 946 production and of rubella virus interference in a line of African green monkey kidney cells 947 (Vero). J Virol 2, 955-961.

948 Fajgenbaum, D.C., and June, C.H. (2020). Cytokine Storm. N Engl J Med 383, 22559492273.

950 Follenzi, A., Ailles, L.E., Bakovic, S., Geuna, M., and Naldini, L. (2000). Gene 951 transfer by lentiviral vectors is limited by nuclear translocation and rescued by HIV-1 pol 952 sequences. Nat Genet 25, 217-222. 
954 Vendruscolo, M., and Cavalli, A. (2014). ALMOST: an all atom molecular simulation toolkit for protein structure determination. J Comput Chem 35, 1101-1105.

$\mathrm{Hu}, \mathrm{Y}$., et al. (2020). Highly pathogenic coronavirus $\mathrm{N}$ protein aggravates lung injury by

MASP-2-mediated complement over-activation. medRxiv,

960

Garlanda, C., Bottazzi, B., Magrini, E., Inforzato, A., and Mantovani, A. (2018).

PTX3, a Humoral Pattern Recognition Molecule, in Innate Immunity, Tissue Repair, and

Garred, P., Pressler, T., Lanng, S., Madsen, H.O., Moser, C., Laursen, I., Balstrup, F., Koch, C., and Koch, C. (2002). Mannose-binding lectin (MBL) therapy in an MBL-deficient patient with severe cystic fibrosis lung disease. Pediatr Pulmonol 33, 201-207.

966

Han, B., Ma, X., Zhang, J., Zhang, Y., Bai, X., Hwang, D.M., Keshavjee, S., Levy,

G.A., McGilvray, I., and Liu, M. (2012). Protective effects of long pentraxin PTX3 on lung

Holmskov, U., Thiel, S., and Jensenius, J.C. (2003). Collections and ficolins: humoral lectins of the innate immune defense. Annu Rev Immunol 21, 547-578.

Ip, W.K., Chan, K.H., Law, H.K., Tso, G.H., Kong, E.K., Wong, W.H., To, Y.F., Yung, R.W., Chow, E.Y., Au, K.L., et al. (2005). Mannose-binding lectin in severe acute respiratory syndrome coronavirus infection. J Infect Dis 191, 1697-1704.

Jensenius, J.C., Jensen, P.H., McGuire, K., Larsen, J.L., and Thiel, S. (2003). Recombinant mannan-binding lectin (MBL) for therapy. Biochem Soc Trans 31, 763-767. Nucleocapsid and Spike Proteins of the Coronavirus SARS-CoV-2 Induce IL6 in Monocytes and Macrophages-Potential Implications for Cytokine Storm Syndrome. Vaccines (Basel) 9, 54.

King, C., and Sprent, J. (2021). Dual Nature of Type I Interferons in SARS-CoV-2Induced Inflammation. Trends Immunol 42, 312-322.

Koch, A., Melbye, M., Sorensen, P., Homoe, P., Madsen, H.O., Molbak, K., Hansen, 

antibodies. bioRxiv, doi.org/10.1101/2021.04.03.438258.

Lipscombe, R.J., Sumiya, M., Hill, A.V., Lau, Y.L., Levinsky, R.J., Summerfield,

992

993

994

995

996

997

998

999

1000

1001

1002

1003

1004

1005

1006

1007

1008

1009

1010

1011

1012

1013

1014

1015

1016

1017

1018

1019

J.A., and Turner, M.W. (1992). High frequencies in African and non-African populations of independent mutations in the mannose binding protein gene. Hum Mol Genet 1, 709-715.

Lu, Q., Liu, J., Zhao, S., Gomez Castro, M.F., Laurent-Rolle, M., Dong, J., Ran, X., Damani-Yokota, P., Tang, H., Karakousi, T., et al. (2021). SARS-CoV-2 exacerbates proinflammatory responses in myeloid cells through C-type lectin receptors and Tweety family member 2. Immunity. doi: 10.1016/j.immuni.2021.05.006. In press.

Madsen, H.O., Garred, P., Kurtzhals, J.A., Lamm, L.U., Ryder, L.P., Thiel, S., and Svejgaard, A. (1994). A new frequent allele is the missing link in the structural polymorphism of the human mannan-binding protein. Immunogenetics 40, 37-44.

Madsen, H.O., Garred, P., Thiel, S., Kurtzhals, J.A., Lamm, L.U., Ryder, L.P., and Svejgaard, A. (1995). Interplay between promoter and structural gene variants control basal serum level of mannan-binding protein. J Immunol 155, 3013-3020.

Mantel, N., and Haenszel, W. (1959). Statistical aspects of the analysis of data from retrospective studies of disease. J Natl Cancer Inst 22, 719-748.

McBride, R., van Zyl, M., and Fielding, B.C. (2014). The coronavirus nucleocapsid is a multifunctional protein. Viruses 6, 2991-3018.

Medetalibeyoglu, A., Bahat, G., Senkal, N., Kose, M., Avci, K., Sayin, G.Y., IsogluAlkac, U., Tukek, T., and Pehlivan, S. (2021). Mannose binding lectin gene 2 (rs1800450) missense variant may contribute to development and severity of COVID-19 infection. Infect Genet Evol 89, 104717.

Merad, M., and Martin, J.C. (2020). Pathological inflammation in patients with COVID-19: a key role for monocytes and macrophages. Nat Rev Immunol 20, 355-362.

Mycroft-West, C.J., Su, D., Pagani, I., Rudd, T.R., Elli, S., Gandhi, N.S., Guimond, S.E., Miller, G.J., Meneghetti, M.C.Z., Nader, H.B., et al. (2020). Heparin Inhibits Cellular Invasion by SARS-CoV-2: Structural Dependence of the Interaction of the Spike S1 Receptor-Binding Domain with Heparin. Thromb Haemost 120, 1700-1715.

Myocardial Infarction Genetics, C., Kathiresan, S., Voight, B.F., Purcell, S., Musunuru, K., Ardissino, D., Mannucci, P.M., Anand, S., Engert, J.C., Samani, N.J., et al. 
medRxiv preprint doi: https://doi.org/10.1101/2021.06.07.21258350; this version posted June 8, 2021. The copyright holder for this preprint (which was not certified by peer review) is the author/funder, who has granted medRxiv a license to display the preprint in perpetuity. All rights reserved. No reuse allowed without permission.

1020

1021

1022

1023

1024

1025

1026

1027

1028

1029

1030

1031

1032

1033

1034

1035

1036

1037

1038

1039

1040

1041

1042

1043

1044

1045

1046

1047

1048

1049

1050

1051

1052

1053

(2009). Genome-wide association of early-onset myocardial infarction with single nucleotide polymorphisms and copy number variants. Nat Genet 41, 334-341.

Ng, K.K., Kolatkar, A.R., Park-Snyder, S., Feinberg, H., Clark, D.A., Drickamer, K., and Weis, W.I. (2002). Orientation of bound ligands in mannose-binding proteins.

Implications for multivalent ligand recognition. J Biol Chem 277, 16088-16095.

Pairo-Castineira, E., Clohisey, S., Klaric, L., Bretherick, A.D., Rawlik, K., Pasko, D., Walker, S., Parkinson, N., Fourman, M.H., Russell, C.D., et al. (2021). Genetic mechanisms of critical illness in COVID-19. Nature 591, 92-98.

Purcell, S., Neale, B., Todd-Brown, K., Thomas, L., Ferreira, M.A., Bender, D., Maller, J., Sklar, P., de Bakker, P.I., Daly, M.J., et al. (2007). PLINK: a tool set for wholegenome association and population-based linkage analyses. Am J Hum Genet 81, 559-575.

Reading, P.C., Bozza, S., Gilbertson, B., Tate, M., Moretti, S., Job, E.R., Crouch, E.C., Brooks, A.G., Brown, L.E., Bottazzi, B., et al. (2008). Antiviral Activity of the Long Chain Pentraxin PTX3 against Influenza Viruses. J Immunol 180, 3391-3398.

Risitano, A.M., Mastellos, D.C., Huber-Lang, M., Yancopoulou, D., Garlanda, C., Ciceri, F., and Lambris, J.D. (2020). Complement as a target in COVID-19? Nat Rev Immunol 20, 343-344.

Schirinzi, A., Pesce, F., Laterza, R., D'Alise, M.G., Lovero, R., Fontana, A., Contino, R., and Di Serio, F. (2021). Pentraxin 3: Potential prognostic role in SARS-CoV-2 patients admitted to the emergency department. J Infect 82, 84-123.

Scudieri, P., Caci, E., Bruno, S., Ferrera, L., Schiavon, M., Sondo, E., Tomati, V., Gianotti, A., Zegarra-Moran, O., Pedemonte, N., et al. (2012). Association of TMEM16A chloride channel overexpression with airway goblet cell metaplasia. J Physiol 590, 61416155.

Severe Covid, G.G., Ellinghaus, D., Degenhardt, F., Bujanda, L., Buti, M., Albillos, A., Invernizzi, P., Fernandez, J., Prati, D., Baselli, G., et al. (2020). Genomewide Association Study of Severe Covid-19 with Respiratory Failure. N Engl J Med 383, 1522-1534.

Sheriff, S., Chang, C.Y., and Ezekowitz, R.A.B. (1994). Human mannose-binding protein carbohydrate recognition domain trimerizes through a triple $\alpha$-helical coiled-coil. Nat Struct Biol 1, 789-794.

Stravalaci, M., Davi, F., Parente, R., Gobbi, M., Bottazzi, B., Mantovani, A., Day, A.J., Clark, S.J., Romano, M.R., and Inforzato, A. (2020). Control of Complement Activation by the Long Pentraxin PTX3: Implications in Age-Related Macular Degeneration. Front Pharmacol 11, 591908. 

Summerfield, J.A. (1991). Molecular basis of opsonic defect in immunodeficient children. Lancet 337, 1569-1570.

Taliun, D., Harris, D.N., Kessler, M.D., Carlson, J., Szpiech, Z.A., Torres, R., Taliun, S.A.G., Corvelo, A., Gogarten, S.M., Kang, H.M., et al. (2021). Sequencing of 53,831 diverse genomes from the NHLBI TOPMed Program. Nature 590, 290-299.

Wang, J., Jiang, M., Chen, X., and Montaner, L.J. (2020). Cytokine storm and leukocyte changes in mild versus severe SARS-CoV-2 infection: Review of 3939 COVID-19 patients in China and emerging pathogenesis and therapy concepts. J Leukoc Biol 108, 17-41. specific glycan analysis of the SARS-CoV-2 spike. Science 369, 330-333.

Wu, F., Zhao, S., Yu, B., Chen, Y.M., Wang, W., Song, Z.G., Hu, Y., Tao, Z.W., Tian, J.H., Pei, Y.Y., et al. (2020). A new coronavirus associated with human respiratory disease in China. Nature 579, 265-269.

Yuan, F.F., Tanner, J., Chan, P.K., Biffin, S., Dyer, W.B., Geczy, A.F., Tang, J.W., Hui, D.S., Sung, J.J., and Sullivan, J.S. (2005). Influence of FcgammaRIIA and MBL polymorphisms on severe acute respiratory syndrome. Tissue Antigens 66, 291-296. Yang, Y., Xie, J., et al. (2020). Biochemical characterization of SARS-CoV-2 nucleocapsid protein. Biochem Biophys Res Commun 527, 618-623.

Zhang, H., Zhou, G., Zhi, L., Yang, H., Zhai, Y., Dong, X., Zhang, X., Gao, X., Zhu, Y., and He, F. (2005). Association between mannose-binding lectin gene polymorphisms and susceptibility to severe acute respiratory syndrome coronavirus infection. J Infect Dis 192, $1355-1361$.

Zhang, Q., Bastard, P., Liu, Z., Le Pen, J., Moncada-Velez, M., Chen, J., Ogishi, M., Sabli, I.K.D., Hodeib, S., Korol, C., et al. (2020). Inborn errors of type I IFN immunity in patients with life-threatening COVID-19. Science 370, eabd4570. and Simmons, G. (2010). A single asparagine-linked glycosylation site of the severe acute respiratory syndrome coronavirus spike glycoprotein facilitates inhibition by mannosebinding lectin through multiple mechanisms. J Virol 84, 8753-8764. 
medRxiv preprint doi: https://doi.org/10.1101/2021.06.07.21258350; this version posted June 8, 2021. The copyright holder for this preprint (which was not certified by peer review) is the author/funder, who has granted medRxiv a license to display the preprint in perpetuity.

All rights reserved. No reuse allowed without permission. 